\title{
Emerging Economy Inward and Outward Foreign Direct Investment: A Bibliometric and Thematic Content Analysis
}

\author{
Keilla Dayane da Silva-Oliveira, ${ }^{1,3} \cdot$ Edson Keyso de Miranda Kubo $^{1}{ }^{(\mathbb{D}} \cdot$ \\ Michael J. Morley ${ }^{2}\left[\right.$ - Rodrigo Médici Cândido ${ }^{1} \mathbb{D}$
}

Received: 18 June 2020 / Revised: 15 June 2021 / Accepted: 22 June 2021 /

Published online: 16 September 2021

(c) The Author(s) 2021

\begin{abstract}
Research examining emerging economy inward and outward foreign direct investment (FDI) flows is on a significant upward trajectory. In this bibliometric analysis covering 806 articles published between 1994 and 2019, we map key aspects of its contours. Our analysis proceeds in two sequential phases involving a performance analysis, followed by a thematic analysis. Our performance analysis unveils fundamental elements of the structure of the knowledge base. Our subsequent thematic analysis identifies three focal topics arising from identifiable shared qualities characterizing this literature. Firstly, we distinguish scholarship focused on inward FDI into emerging economies formed by two particular classes, namely 'innovative FDI' and 'capital flows'. Our second theme covers outward FDI from these emerging economies and also comprises two specific classes referring to the 'institutional environment' and the 'theoretical framework deployed'. Our final theme relates to an integrated body of knowledge explicating aspects of the location choice decision. Building on this analysis, we isolate a number of opportunities for future research.
\end{abstract}

Keywords Emerging economies $\cdot$ Foreign direct investment $\cdot$ Multinational enterprises $\cdot$ Bibliometric analysis

Michael J. Morley

michael.morley@ul.ie

1 Universidade Municipal de São Caetano do Sul (USCS), São Caetano do Sul, Brazil

2 Kemmy Business School, University of Limerick, Limerick V94 T9PX, Ireland

3 Universidade Federal do Mato Grosso do Sula , Três Lagoas, Mato Grosso do Sul, Brazil 


\section{Introduction}

Over the past two decades, there has been a significant growth in the international business (IB) literature on foreign direct investment (FDI), in particular into and from the emerging economies (Borin \& Mancini, 2016; Danakol et al., 2017; Iamsiraroj, 2016; Neumayer et al., 2016; Nielsen et al., 2017; Pinto \& Zhu, 2009). Defined as "the establishment of a lasting interest in, and significant degree of influence over, the operations of an enterprise in one economy by an investor in another economy" (OECD, 2015, p. 5), the particular attention afforded FDI in the emerging economy context is hardly surprising. As Korinek (2017) highlights from an investment perspective, these economies have offered the prospect of higher growth opportunities than some of their developed counterparts with the result that they have proven especially attractive for inward FDI. Data from the International Monetary Fund (IMF) confirms the growth pattern among emerging economies, making them an important engine for overall global growth (IMF, 2018). Furthermore, data from the World Bank (2019), presented in the most recent Global Economic Prospects Report, show that the real Gross Domestic Product (GDP) growth of emerging economies between 2016 and 2017 outstripped both the real GDP growth of developed economies, and that of the world average. Thus, while world GDP growth rates were $2.4 \%$ and $3.1 \%$ respectively in the years 2016 and 2017, the equivalent rates for developed economies were $1.7 \%$ and $2.3 \%$, while the rates for emerging economies stood at $3.7 \%$ and $4.3 \%$.

Against the backdrop of this trajectory, we offer an assessment of the scholarly literature on FDI in the emerging economy context. In providing an exposition and classification of the body of work, we make a number of contributions to the field as follows. Firstly, we establish the root trajectories of the scholarship including for example tracing the outlets where it is published, the countries from which it comes, and the impact it has had. Secondly, we identify key research co-authorship networks in the field. Thirdly, through a thematic content analysis, we unearth the dominant themes that have been explored in the literature and we identify content categories arising from shared qualities that categorize the body of work to-date. In this way we seek to bring systematics to aspects of the scholarship on emerging economy FDI and advance understanding of key elements of the phenomenon in a more holistic way. In curating and organizing this body of work, we highlight particular knowledge gaps. We distill three types of FDI which we classify as Conservative, Bold and Moderate and we call attention to a number of prospective research opportunities. Since an amount of scholarship has relied on institutional and resourcedependency ideas, we suggest that the deployment of additional theoretical lenses may serve to cast light on different aspects of FDI in this context. Thus, for example, there may be particular value in further spotlighting variations between subnational regions in emerging economies and the experiences of the EMNEs in their respective subnational contexts. Prevailing aspects of these subnational contexts are central to unravelling influences on the performance of subsidiaries (Deng, 2009; Luo et al., 2010; Meyer et al., 2009; Stallkamp et al., 2018; Yiu et al., 2007). The management styles of EMNEs and their ownership advantages, along with the reasons for 
internationalization may also merit more attention. Similarly, a greater focus on the volatility of emerging markets due to the different types of risks and a more in-depth understanding of institutional distance between emerging economies may generate additional insights (Hu \& Cui, 2014; Luo et al., 2010; Sanfilippo, 2015). Overall, therefore, through the application of both bibliometric techniques and thematic content analysis, particularly following what has been a period of sustained growth in scholarship, we take stock of the contours of the knowledge base, we synthesize key findings, and we signpost possible future research avenues.

The remainder of our paper proceeds as follows. Firstly, to connect with the background literature, we briefly outline definitional issues and classifications pertaining to emerging economies and FDI. We then describe the process we followed in generating our bibliometric data. This is followed by a presentation of our results encompassing both our performance analysis and our thematic content analysis. The former includes inter alia, the most cited documents, a co-citation analysis and key word co-occurrence analysis, while the latter isolates key themes, lenses and theories informing the body of work to-date. Finally, we synthesize the key findings emerging from our analysis and we identify possible research questions.

\section{Background}

FDI is frequently viewed as a fundamental part of the architecture of an economy's developmental trajectory, in particular in the case of emerging economies. Many go to significant lengths to highlight the locational, institutional and human capital endowments that they possess which make them particularly attractive host locations for inward FDI flows. In emerging economies with institutional environments characterized by resource constraints, relatively light-touch regulation, but a concomitant capacity from frugal innovation, playing host to FDI is a necessary plank of the economic developmental modet (Horwitz \& Budhwar, 2015; Modou \& Yun, 2017; Peng, 2001; Yiu et al., 2007; Zeschky et al., 2011). Among other things, this FDI contributes to their respective balance of payments, provides exchange rate stability, reduces the volatility of the economy, and ensures greater predictability for economic agents in general (Ayme, 2003; Bhat \& Bhat, 2021).

The emerging economies which succeed in attracting FDI, Iamsiraroj (2016) highlights, do so for several reasons including the provision of access to advanced technology, the development of core competences, the exhibiting of research and development capabilities, and the provision of financial incentives, the combination of which are offered as essential assets to stimulate creativity and economic development. The benefits accruing to the host location and the MNE represent a combination of significant employment generation, productivity expansion and costs reduction (Borin \& Mancini, 2016).

The particular interest in emerging economies by MNEs is illustrated by the fact that inward flows of FDI into these economies in 2017 alone amounted to some $\$ 671$ billion dollars, making MNEs a significant source of external financing for the emerging economies of the last decade, in comparison with the other available sources. Amatucci and Avrichir (2008) highlight that the MNEs FDI decision 
revolves around several key considerations, including for example an assessment of the tax barriers imposed by each country and their infrastructure, access to raw material, and the likely prevailing political and social conditions. Yang et al. (2013) also point out that the location, infrastructure, political stability, transportation costs, quality of work and commerce flow of the country represent important contextual considerations governing the decision relating to the destination of the FDI. MNEs make gains by combining different resources and exploring new markets, while the emerging economies seek to attract FDI by emphasizing their location specific advantages.

\section{Data and Methods}

Bibliometric research involving the identification, curation, and statistical analysis of a defined body of academic communication contained in publications makes it possible to evaluate the scientific contours of a domain area of scholarship, along with the nature and direction of its development over time (Merigó et al., 2016; Ruas \& Pereira, 2014; van Eck \& Waltman, 2014; van Leeuwen, 2006; van Leeuwen et al., 2003; van Raan, 2005). Following the methodological proposal made by LopezFernandez et al. (2016), the database that we assembled and analyzed on emerging market inward and outward FDI is derived from the Web of Science (WoS) core collection and involved a six-stage process as set out in Fig. 1 below.

We started with a comprehensive data-base search in the WoS. It allows for the harvesting of data from a suite of journals and is recognized as a reliable database for conducting bibliometric studies (Ding et al., 2014). To identify the sample for our study, two filters were employed: The first filter used the search string "foreign direct investment" and "FDI" in the title, summary, and keywords fields, which resulted in 11,319 selected articles. The second filter used the string "emerging

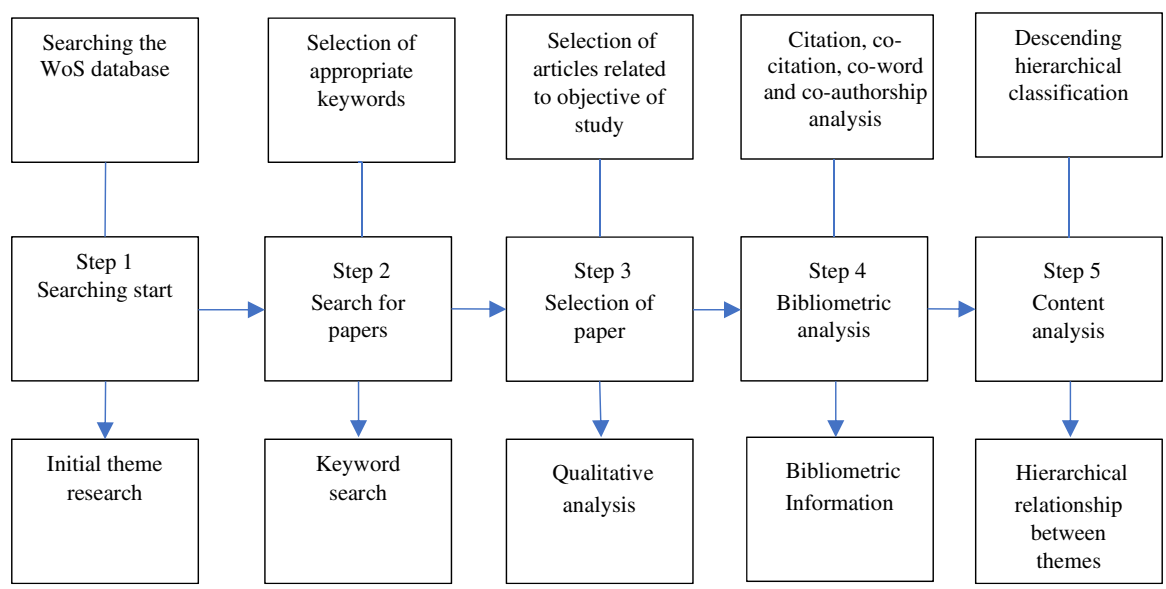

Fig. 1 Data assembly and analysis 
market", "emerging economy" or "emerging economies", using the search in the same fields as the first filter yielded 9,804 articles. The subsequent combining of the two filters resulted in 806 relevant articles for inclusion spanning the period 1994 to 2019. We then engaged in a bibliometric and thematic analysis of the body of work selected. Two main bibliometric techniques were used: performance analysis and scientific mapping. As an approach, bibliometric analysis can contribute to the generation of deeper insights into the scientific intellectual structure underpinning a body of work and to an understanding of how arguments are built, and how knowledge accumulates in publications in sequence (White \& Griffith, 1981). It facilitates the identification of key authors through records and citations (White \& Mccain, 1998). Furthermore, co-citation analysis connects specific published research (Leydesdorff, 2005; McCain, 1990), and a fundamental mapping of the cited and cocited articles offers the possibility of a fuller understanding of the building blocks and trajectory of a research field (Ding et al., 2000). To obtain clusters and identify co-authorship networks, methodological guidelines proposed by van Eck and Waltman (2014) in the conducting and generation of bibliometric network visualizations were used. VOSviewer software was employed to create the bibliometric maps developed as part of our analysis.

After establishing key bibliometric characteristics, Iramuteq 0.7 software was used to perform a textual content analysis (Bardin, 2011). This facilitates the classifying of the articles into thematic groups and enables a fuller understanding of the hierarchical relationship between them based on elements of their content (Reinert, 1990). We used Descending Hierarchical Classification (DHC) to classify text segments based on their respective vocabularies. The criteria for including elements in their classes was words with a higher frequency than the medium frequency of the entire corpus, as well as an association with the class determined by the chisquare value equal to or greater than 3.84 ( $\mathrm{p}<0.05)$. This classification allowed us to obtain classes of text segments with vocabulary similar to each other and at the same time different from the text segments of the other classes. The method systematizes the analysis of different texts in a dendrogram, which graphically organizes the classes and their possible relations.

\section{Results}

\subsection{General Results}

It is clear from the results presented in Fig. 2, the focal body of scholarly research is on a significant upward trajectory. We identified some 806 Web of Science articles, classified in the areas of business, management, economics, finance, planning, development and international relations. The total number of citations produced by this suite of articles stands at 18,025, with an accompanying h-index of 63, and an average citation rate of 22.48 per article. 


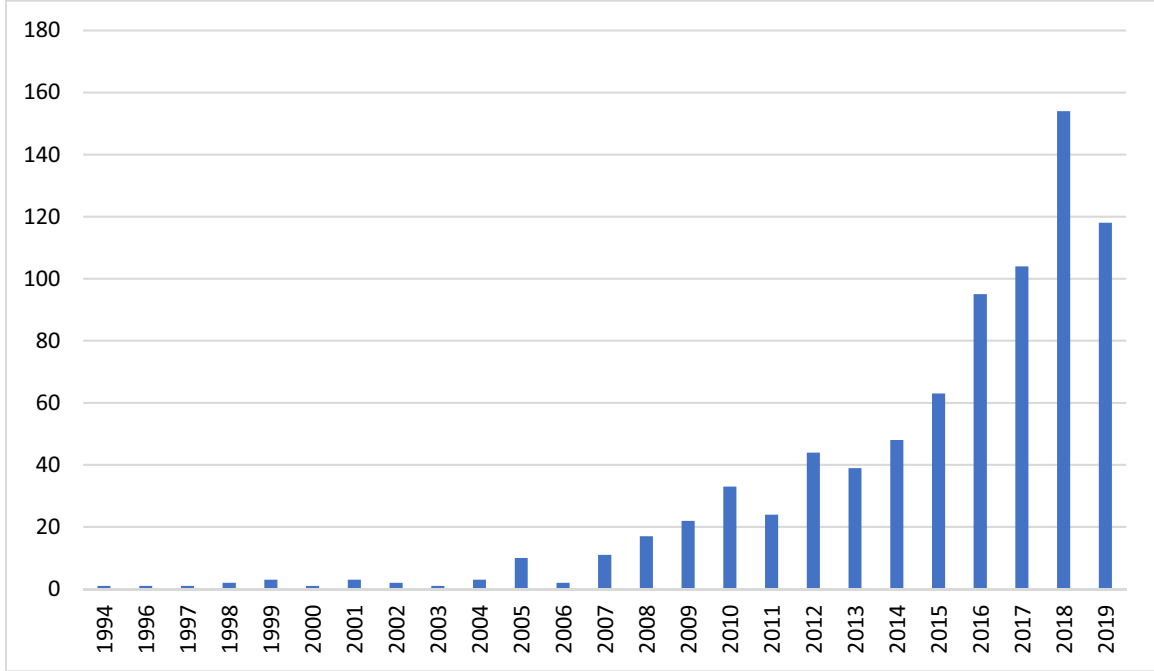

Fig. 2 Publications by year

\subsection{Publications by Year}

This body of work has been produced by 1,408 authors affiliated to 844 institutions across 71 countries and is published in a total of 262 journals. With respect to the distribution of publications by year we cover the period from 1994 to 2019. The number of studies between 1994 and 2006 remained relatively low. However, since 2007 research on FDI in the emerging economies has been on a significant upward trajectory. Of note, $58.43 \%$ of the articles in our analysis were published in the last four years (95 articles in 2016, 104 in 2017, 154 in 2018 and 118 in 2019), underscoring once again the significant interest that currently exists in this domain area of research as a result of the narrowing of the basis of competitiveness in many mature economies and the shifting of much global economic power to emerging economies. Not only have they moved from the periphery to the center of much global IB activity, but also to the center of many scholars' academic research agendas.

\subsection{Most Cited Documents}

Turning to the issue of citation, the average citation rate for the total 806 articles under analysis here stands at 22.48 . However, almost $16 \%$ of the articles were never cited, while only $10.54 \%$ were cited more than fifty times. The top five most cited articles (Table 1), which for illustrative purposes we provide a précis of below, have been cited more than 1900 times.

With an accumulated total of 745 citations the article "Institutions, Resources and Entry Strategies in Emerging Economies" (Meyer et al., 2009) is the most cited article in the period covered by our analysis. This study sought to identify the strategies pursued by foreign companies when entering emerging economies, highlighting the 


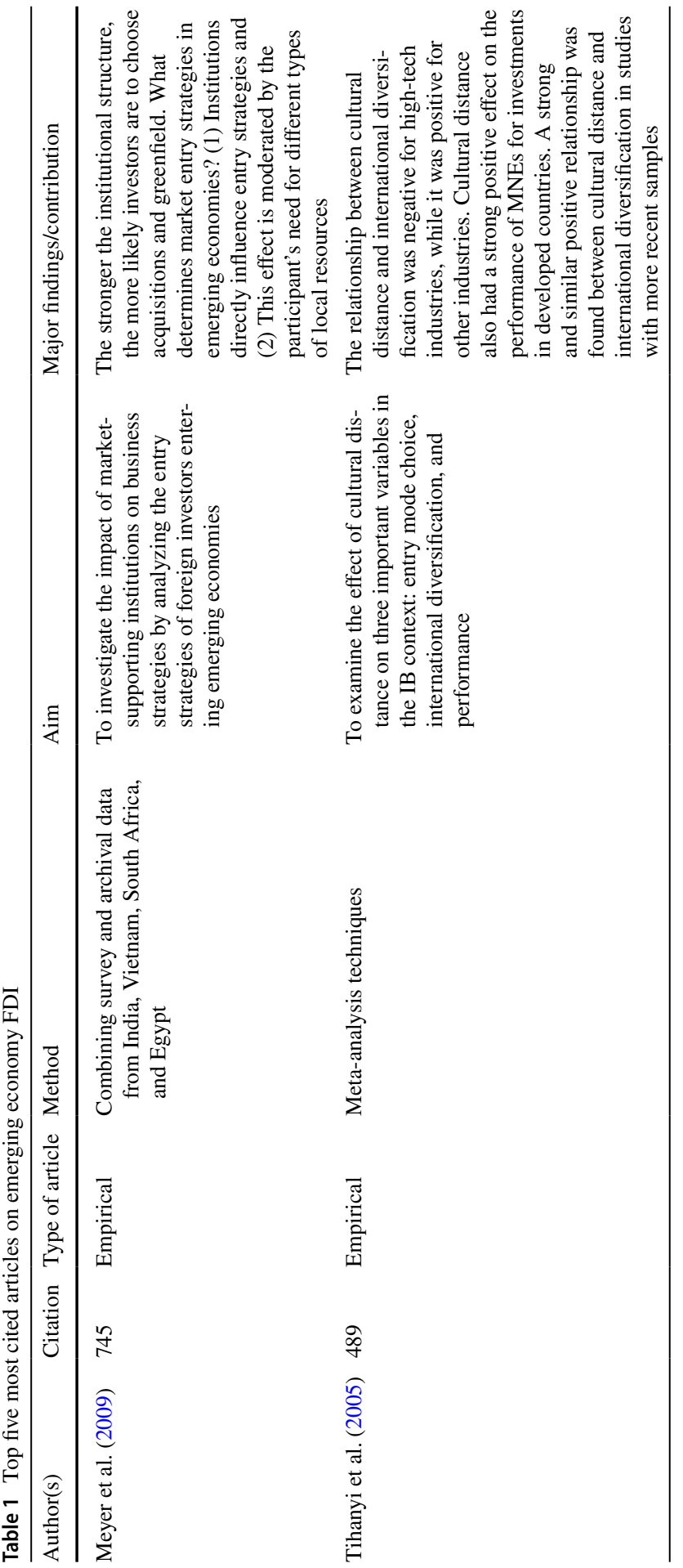




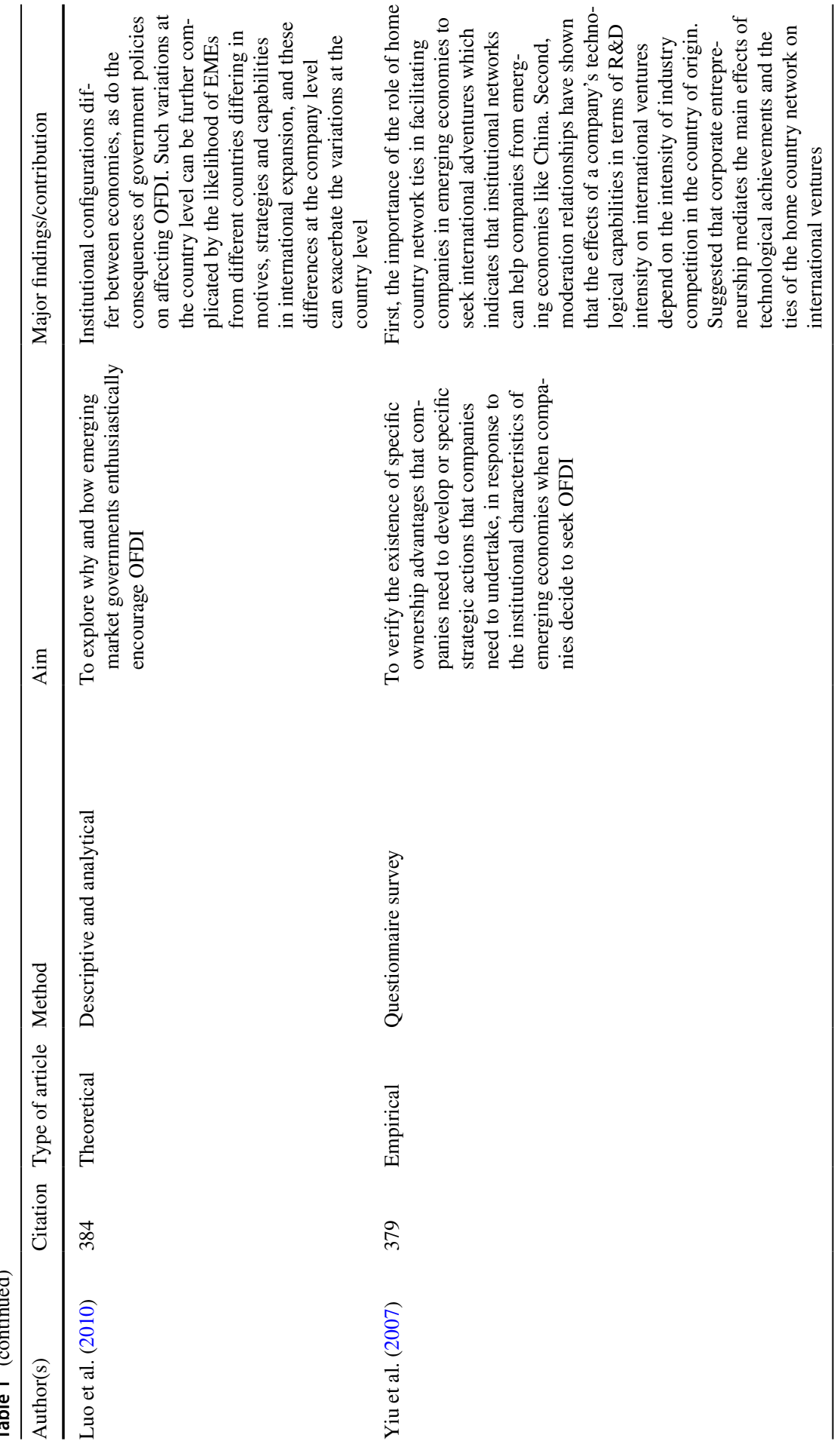




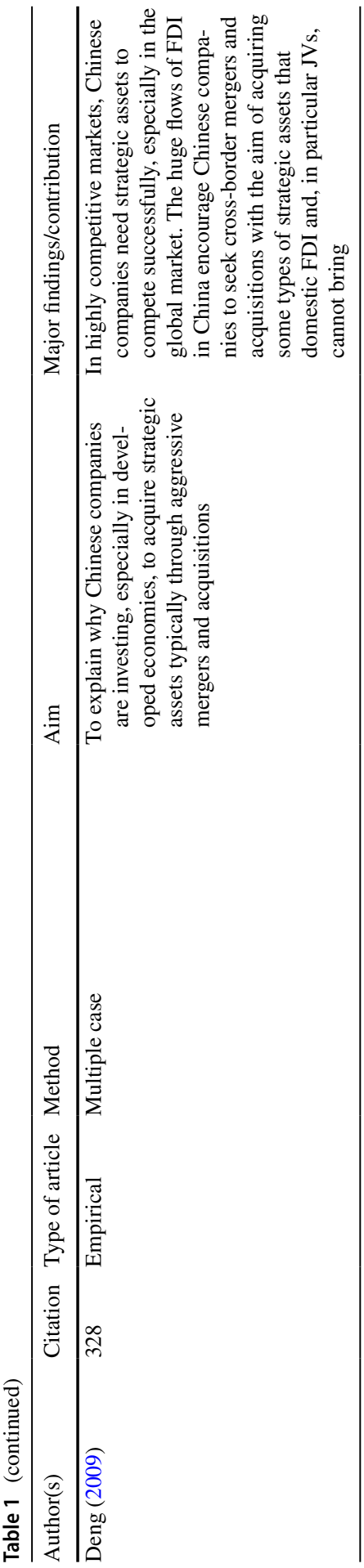


impact of the institutions that offer support. The data employed in the analysis came from India, Vietnam, South Africa, and Egypt. The authors suggest that, among the key determinants of the strategies for entering the emerging economies are, the influence of the institutions, along with the needs for different local resources. Furthermore, they call attention to the simultaneous impact of both the prevailing institutional characteristics and resources relating to the efficiency of the markets, especially the stake of foreign players in local resources, both tangible and intangible.

With a total of 489 citations, the contribution by Tihanyi et al. (2005) titled "The effect of cultural distance on entry mode choice, international diversification, and MNE performance: a meta-analysis" emerges as the second most cited article in the body of work under consideration. The authors conducted a meta-analysis of cultural differences associated with the entry mode choice, international diversification, and the performance of MNEs. As a result, they find a strong negative association between cultural distance and the entry mode choice for US MNEs. The relationship between cultural distance and international diversification was negative for high-tech industries, but positive for other industries and MNEs with investments in developed countries.

The third most cited article is "How emerging market governments promote outward FDI: Experience from China" authored by Luo et al. (2010). It examines how outward FDI made by companies from emerging economies has become more commonplace in the business world. The article offers a detailed analysis of the Chinese context, arguing that the logic of the policies for promoting outward FDI established by the governments of emerging economies are economically imperative and institutionally complementary to compensate for some of the perceived competitive disadvantages attaching to these companies when operating in the globally competitive arena. In addition, the authors highlight how government institutions influence Chinese outward FDI and they discuss key policies and measures that stimulate Chinese companies to expand in the global market.

The fourth most cited is "International venturing by emerging economy firms: the effects of firm capabilities, home country networks, and corporate entrepreneurship" by Yiu et al. (2007). In this contribution, the authors introduce new parameters on the direct relationship between firm-specific ownership advantages and international expansion. The research focused on the particular property advantages and strategic actions that companies need to develop in response to the institutional characteristics of emerging economies when they decide to seek external FDI. The results suggest that the relationship between firm-specific ownership advantages and international ventures is moderated by the degree of competition from national industry and the intensity of exports.

The fifth most cited article titled "Why do Chinese firms tend to acquire strategic assets in international expansion?" by Deng (2009) has also accumulated a total of 328 citations to-date. The study focused on Chinese MNEs that had engaged in mergers or acquisitions with the intention of accessing and obtaining strategic assets to negate aspects of their perceived competitive disadvantage. According to Deng, there is a lack of research examining the actual reasons for these mergers and acquisitions of strategic assets. The article, based on theoretical insights garnered from institutional theory, proposed a motivation model oriented to understanding the 
resources behind Chinese mergers and acquisitions. In order to assess the explanatory power of the proposed institutional framework, the study presents three case studies of leading Chinese companies. It is suggested that the border-crossing mergers and acquisitions of the Chinese companies represent the dominant means for acquiring strategic assets.

\subsection{Co-Citation Analysis}

To understand the theoretical foundations of the body of work, a co-citation analysis was performed with cited references as the analysis unit. The initial sample of 30,516 references was reduced to articles with a minimum of 50 citations, resulting in 52 documents (Fig. 3). Three clusters were identified as follows: Cluster 1 comprising authors whose work has focused on the process of internationalization; Cluster 2 focused on work examining the motivations for internationalization; and Cluster 3 representing the body of work dealing with the internationalization strategies pursued.

Within Cluster 1 focused on explicating internationalization processes, Luo and Tung (2007) argue that emerging market MNEs use international expansion as a lever in order to acquire strategic resources and reduce the institutional and market constraints of the host country. In this way, they seek to overcome certain liabilities, through a series of aggressive risk decisions, acquiring or buying assets of mature MNEs to compensate for perceived existing competitive weaknesses. Furthermore,

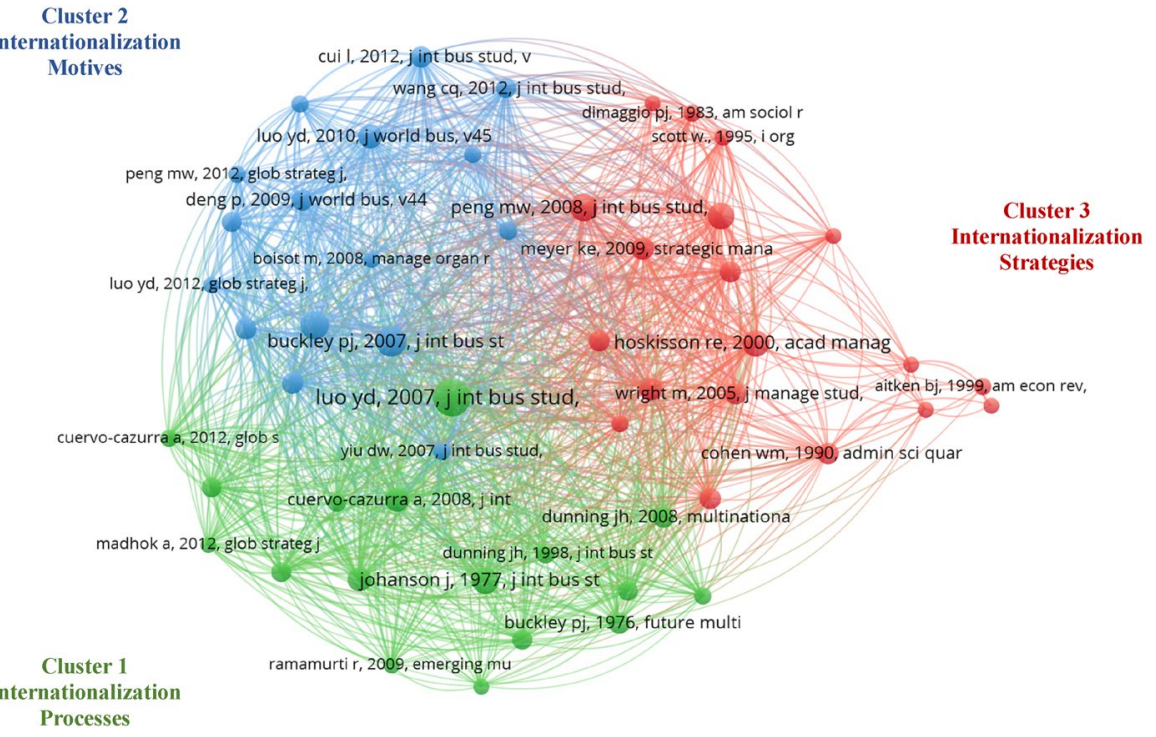

Fig. 3 Co-cited reference clusters 
there are unique features surrounding both the corporate motivations for internationalization and the actual internationalization process pursued in the emerging economy context. Important among these are overcoming the Liability of Foreignness (LOF), the Liability of Newness (LON) and securing access to strategic factors of productions including skilled labor, R\&D and sophisticated markets.

Mathews (2006) reviews the experiences of recently internationalized companies, especially those from Asia, such as Acer, Ispat International, $\mathrm{Li}^{-} \&$ Fung and Hong Leong Group. The innovative features of the MNEs under consideration, such as their fast-paced process of internationalization, strategic innovation and organization innovation are seen to fit particularly well with the features of the emerging global economy, where late mover (emerging economies) and early mover (advanced economies) could combine and benefit from complementarities that could accrue from creating inter-firm linkages. The authors reason that the MNEs adopt a different perspective for the accessed resources through internationalization and that it requires a reconsidering of the criteria normally used in resource-based strategy calculations.

Cluster 2, focused on internationalization motives, includes the work of Buckley et al. (2007), who investigate the determinants of the FDI and the degree to which three explanations relating to imperfections of the stock market, special advantages of institutional property and ownership advantages need to be aligned in the general theory of the MNE. The hypotheses developed were tested using the official Chinese outward FDI data collected between 1984 and 2001. The authors reached the conclusion that Chinese outward FDI is associated with high levels of political risk and cultural approximation with the host countries, with the size of the host market and its geographical proximity, leading to the suggestion that FDI from emerging countries such as China would require a special theory nested within a general theory of FDI.

Child and Rodrigues (2005) also examined the internationalization motivations, beyond mere exporting, among Chinese firms seeking new market opportunities. From a theoretical standpoint, the article compares factors that seem to influence the international expansion of Chinese companies with those rehearsed in existing theory dealing with Chinese firms and with previous research on firms operating in developing countries. The case studies, in combination, suggest that there is a search for technological assets to achieve a competitive positioning in selected international markets. In this way, Chinese companies make their investments to deal with competitive disadvantages, with the purpose of engaging in "internal" internationalization through original equipment manufacturing (OEM) and joint venture partnerships. Concomitantly, "external" internationalization also occurs through acquisitions and organic expansion abroad. Each of the approaches pursued are accompanied by attendant benefits and risks. The authors conclude that the Chinese case offers opportunities to extend current theorization through casting light on several interlinked domains including the value of: (a) a delayed perspective and recovering strategies; (b) institutional analysis with reference to the role of government; (c) the relations between entrepreneurs and institutions, and; (d) the responsibility of foreign parties to the process. 
Cluster 3 represents research focused on the actual internationalization strategies employed by FDI backed firms in emerging economies. Here, Hoskisson, Eden, Lau and Wright (2000), in their research, call attention to the case of emerging economies classified as low income, but with a fast-paced growth trajectory secured through an economic liberation engine. They divide these countries into two groups: developing economies in Asia, Latin America, Africa and Middle East, and transition economies in the former Soviet Union and in China. According to the authors, private and public companies develop exclusive strategies to deal with the swathe of economic and political changes occurring in the emerging economies. Mobilizing theoretical ideas from institutional theory, transaction costs economy and vision based on the firm's resources, they highlight how such different theoretical perspectives can provide useful insights into the formulation and the implementation of strategies by private and public companies in several regional scenarios. Meyer et al. (2009) investigated the impact of institutions that provide market support with the business strategies being pursued to analyze the approaches adopted by foreign investors in entering emerging economies. Theoretically, the authors draw on institutional and resource-based thinking and highlight how resource seeking strategies are made using different entry modes in different institutional contexts. Thus, alternative entry modes such as greenfield investments, acquisitions and joint ventures provide opportunities for companies to overcome different types of market influences related to resource features, as well as to the institutional context.

Against the backdrop of the significant interest of researchers in various aspects of the emerging economies, Peng et al. (2008) call attention to the institutional vision surrounding the IB strategies. They review four key areas: (1) antidumping as an entry barrier; (2) competition in and out of India; (3) growth of the firm in China; and (4) the governing of the corporation in emerging economies. In general, the authors argue that an institutional vision of IB strategy, combined with the visions based on the industry and on the resources, helps not only to maintain a strategic tripod, but also to shed meaningful light on the most fundamental issues faced by the IB.

\subsection{Keyword Co-Occurrence Analysis}

From the articles included in our analysis, we curated a total of 2,375 keywords suggested by the authors in originally classifying their work. The keywords analysis allows for an exploration of the intensity of association between information items and textual data. It also facilitates the identification of the co-occurrence of pairs of items which are representative of a document in order to identify relationships among the ideas presented in the texts. Considering this, we selected from our sample the occurrence and co-occurrence of the keywords used in the classification of each article. These data were then submitted to a normalization process, through VOSviewer software. We focused on the association strength index which has advantages over other direct similarity measures. In calculating the strength coefficient, it is possible to locate subgroups of words that are linked together and the 
strength of these links, which characterize clusters considered to be nuclei of interest within a given theme. For the purposes of our analysis, we set a threshold of 25 as the minimum number of keyword occurrence to limit the analysis to those terms which showed up more in the analyzed literature.

In the co-authorship network, the size of the knots and words characterize the weight of the knots (Fig. 4). The bigger the knot and the word as depicted in the visual, the greater its weight. The distance between two knots expresses the strength of the relationship between them with a smaller distance indicating a stronger relationship. The line existing between two keywords shows that they emerge jointly, while its thickness represents their co-occurrence frequency. In applying a restriction of 25 occurrences for the keyword, the total number was reduced to 76 words. The results of the analysis visibly point to an aggregation around three clearly identifiable clusters.

\subsection{Keyword Analysis}

Cluster 1 here labelled the "Conservative FDI Cluster" covers acquisitions, business groups, Chinese firms, economies, emerging markets, international expansion, internationalization, location choice, MNEs, outward FDI, performance, perspective, and strategies. At its core lies a traditional FDI approach characterized by the premise of market dominance and a view of subsidiaries as highly competitive production platforms offering comparative advantages. In this body of work, research related to the acquisition of local firms and subsidiaries with conservative roles in the exploration of the local market was observed. A case

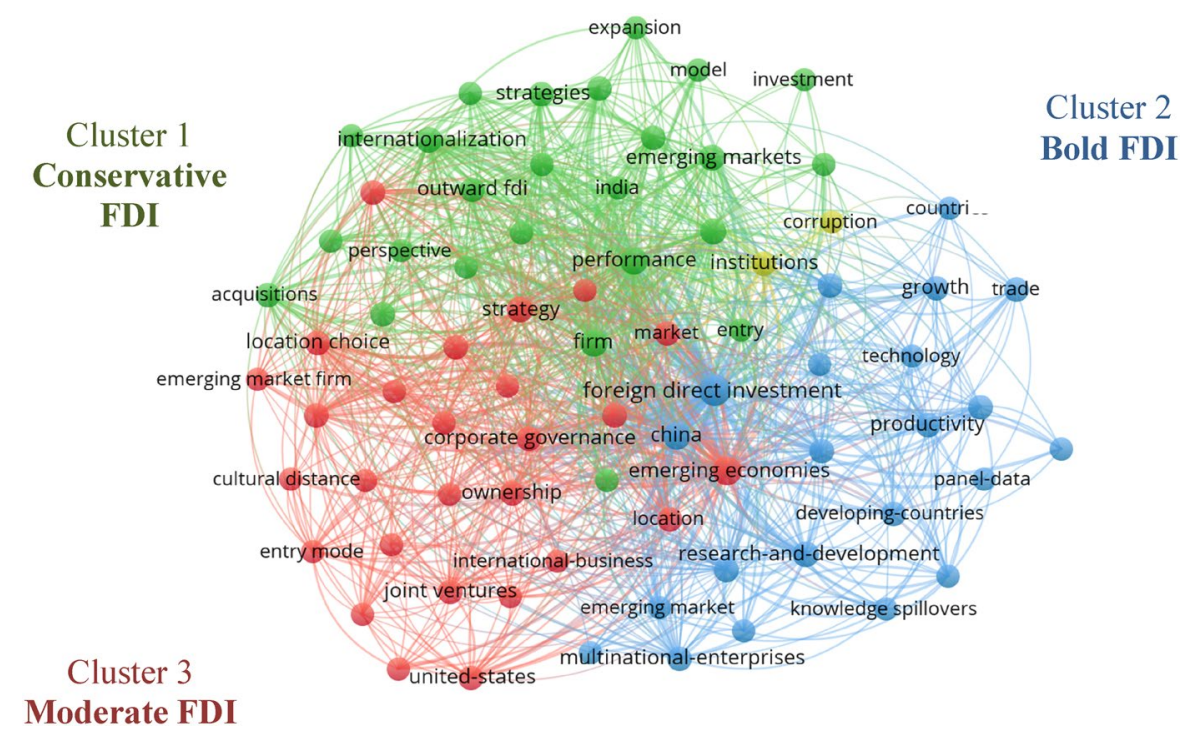

Fig. 4 Keyword clusters 
in point in this regard is the paper titled "Outward foreign direct investment of publicly listed firms from China: A corporate governance perspective" by $\mathrm{Hu}$ and Cui (2014). It examined the influence of the main factors of corporate governance in the internationalization decisions of emerging economy MNEs. Using theoretical arguments from the resource-based view and agency theory, the authors investigated the effects of the controlling owner's identity, the ownership of noncontrolling shareholders and their interactions with the CEO's power to reveal their individual and joint effects on outward FDI. The results suggest that shareholder resource support to companies' outward FDI depends on the CEO's level of power. The authors found that some shareholders are more concerned with agency issues than others because their financial resources are more vulnerable to the agency's behavior. Therefore, in the search for factors governing internationalization of the firm and its approach to corporate governance, CEO ownership and power hold explanatory power.

On the whole, research in this conservative FDI category tends to view emerging economies as places of high risk and volatility and there are fewer references to the availability of local skills or to the learning benefits. Emerging economies are generally observed from the perspective of traditional theories of internationalization, highlighting institutional instability and institutional voids. There is an acknowledgement that FDI in emerging economies can enjoy benefits if there is a concerted effort to overcome local challenges, in terms of customers, competitors and regulators. Unsurprisingly however Chinese FDI in this context demonstrates less of a focus on political risk arising from the governmental protection afforded many. On the whole, the greater the dependence on the government the lesser the incentive to internationalization. EMNEs with government protection have power, but they tend not to be driven less by the logic of diversification. Therefore, the FDI of Chinese government backed MNEs enjoys greater risk tolerance with this backing providing certain protections from aspects of the local macroeconomic challenges that commonly arise including exchange rate instability, fiscal risk, inflation, and legal uncertainty (Hu \& Cui, 2014; Sanfilippo, 2015).

Cluster 2 labeled the "Bold FDI Cluster" comprises work focused on, inter alia, absorptive-capacity, corruption, impact, innovation, institutions, knowledge, spillovers and trade. The "bold" nomenclature arises from the general thrust of much of the work focused on subsidiaries as platforms for innovation, technological spillover and absorptive capabilities that emphasize the strategic role of these subsidiaries in emerging countries. Subsidiaries become sources of knowledge and represent strategic assets for headquarters in the development of new perspectives and in the eschewing of ethnocentrism.

Included among the prominent studies in this cluster, is the article titled "Outward foreign direct investment and domestic innovation performance: evidence from China" by Zhou et al. (2019). The authors explore the existence of reverse technology flows arising from outward FDI with the result that domestic companies may improve their technological innovation and productivity due to investment activities abroad. The results showed that the performance of domestic innovation is positively related to outward FDI in developed countries, while it is negatively related to OFDI in transition and emerging economies. In addition, financial development and 
human capital weaken the positive relationship between outward FDI in developed countries and the performance of domestic innovation and also weaken the negative relationship between outward FDI in transition and emerging economies and the performance of domestic innovation.

Overall, in this Bold FDI cluster the central contribution of FDI in emerging economies is a key focus, in particular the potential contribution of technological spillovers and how through absorptive capacities such spillover gains can be internalized. For this to become possible, a developed institutional environment to facilitate IB (e.g., intellectual property law) is important, in addition to establishing international connections aimed at fostering innovation and free trade practices that enhance the greatest transfer of technology. The practices of free trade and licensing have been observed frequently in the economies of Central Asia and Eastern Europe (Fatima, 2017; Zhou et al., 2019).

In addition, there is treatment of the important issue of sustainability and environmental protection practices. Environmental challenges tend to be significant in emerging economies which can be an impediment to FDI. There is no doubt that 'good citizen' companies will be preferred by the host country, and there is international pressure for polluting companies to internalize the environmental costs they generate. The result is that it is not only necessary to observe the benefits of the FDI for a locations economic performance, but also its adherence to good environmental practices. As Brandl et al. (2021) have recently observed, MNE investments in developing countries have both positive and negative impacts, with IB exhibiting a tendency to emphasize the former over the latter.

Our third and final cluster labeled the "Moderate FDI Cluster" comprises a body of work dealing with themes including competitive advantage, corporate governance, cultural distance, entry mode, firm performance, and international joint ventures. The "moderate FDI" denomination is indicative of a suite of contributions focused on valuing local differences and the impact of strategic alliances and modes of entry that envision integration with the local culture of the host country. The cohort of work in the cluster is more polycentric than that represented in the conservative FDI cluster. A particularly illustrative paper in this respect is the contribution by Kuo et al. (2012) titled "The influence of international experience on entry mode choice: Difference between family and non-family firms". This study investigates the different internationalization approaches pursued by family and non-family businesses. The hypotheses advanced were that inexperienced companies prefer to abandon the control of foreign subsidiaries in exchange for the help of local partners and, therefore, will tend to choose a joint venture arrangement. Family businesses, due to their concerns about socio-emotional wealth, have a greater desire to control their affiliates and tend to maintain higher levels of ownership than non-family businesses.

In addition, research that values the skills of subsidiaries in emerging countries and local knowledge features under this cluster. In particular, theories that explicate the idiosyncratic context of emerging economies appear e.g., to understand the case of the Chinese IFDI and OFDI. Institutional theory emerges as the preferred lens for explaining and understanding how FDI enters emerging economies, especially through the establishment of greenfield facilities or through acquisitions, which impact the market value of both developed country MNEs and EMNEs. Understanding the context and historical 
lessons (path dependence) matters in decisions related to the FDI. In many instances, OFDI by EMNEs from emerging economies follow the same logic of reducing transaction costs, as sought by developed countries. MNEs tend to choose a high share of ownership when entering countries with a high institutional distance. The purpose of this is to provide the FDI with greater clarity and protection. In addition, ownership capital by EMNEs in other countries tends to be greater, the higher the institutional distance between the emerging country and the host country (Kao et al., 2013; Kuo et al., 2012).

\subsection{Key Themes, Lenses and Theories in the Literature}

The final part of our review centered on a content analysis of the works under consideration. To perform the analysis, we employed Iramuteq software which facilitated the identification of the distinct themes and the dominant theoretical lenses employed within the literature. Specifically, an analysis involving the association of statistically significant words was performed. The text strata that make up each class were obtained from the textual corpus on the basis that they display similar vocabulary. The classes formed in the Descending Hierarchical Classification (DHC) are presented in Fig. 5.

\begin{tabular}{|c|c|c|c|c|}
\hline $\begin{array}{l}\text { Location } \\
\text { Choice } \\
(13,8 \%)\end{array}$ & $\begin{array}{l}\text { Theoretical } \\
\text { Framework } \\
\text { of FDI } \\
(23,7 \%)\end{array}$ & $\begin{array}{l}\text { Institutional } \\
\text { Environment } \\
(25,7 \%)\end{array}$ & $\begin{array}{l}\text { Innovative } \\
\text { FDI }(22,7 \%)\end{array}$ & $\begin{array}{l}\text { Capital } \\
\text { Flows } \\
(14,1 \%)\end{array}$ \\
\hline $\begin{array}{l}\text { FDI } \\
\text { Emerging } \\
\text { economies } \\
\text { United States } \\
\text { Performance } \\
\text { Location } \\
\text { Choice } \\
\text { Multinational } \\
\text { Enterprise } \\
\text { Absortive } \\
\text { capacity } \\
\text { Competitive } \\
\text { advantage } \\
\text { Corporate } \\
\text { governance } \\
\text { Joint Venture } \\
\text { Business } \\
\text { group } \\
\text { Strategy } \\
\text { International } \\
\text { expansion }\end{array}$ & $\begin{array}{l}\text { Research } \\
\text { Theoretical } \\
\text { Literature } \\
\text { Study Theory } \\
\text { Paper } \\
\text { Approach } \\
\text { Review } \\
\text { Article } \\
\text { Framework } \\
\text { Adopt } \\
\text { Challenge } \\
\text { Case Focus }\end{array}$ & $\begin{array}{l}\text { Firm } \\
\text { Host country } \\
\text { Experience } \\
\text { Institutional } \\
\text { Effects } \\
\text { Resource } \\
\text { Cross border } \\
\text { Institutional } \\
\text { Distance } \\
\text { Behaviour } \\
\text { Relationships } \\
\text { Influence } \\
\text { Government } \\
\text { Decision } \\
\text { Home } \\
\text { Country }\end{array}$ & $\begin{array}{l}\text { Technology } \\
\text { Productivity } \\
\text { Trade } \\
\text { Spillover } \\
\text { Investment } \\
\text { Domestic } \\
\text { Firms Policy } \\
\text { Economy } \\
\text { Supplier } \\
\text { Economy } \\
\text { Growth } \\
\text { Knowledge } \\
\text { Innovation } \\
\text { Local firms } \\
\text { Increase }\end{array}$ & $\begin{array}{l}\text { Capital Flows } \\
\text { Portfolio } \\
\text { Crisis } \\
\text { Exchange } \\
\text { Rate } \\
\text { Debt } \\
\text { Bank } \\
\text { Inflow } \\
\text { Inflation } \\
\text { Currency } \\
\text { Volatility } \\
\text { Period } \\
\text { Macro } \\
\text { economic } \\
\text { Variable }\end{array}$ \\
\hline
\end{tabular}

Fig. 5 DHC classes 
The five classes identified cluster around three particular themes. The first theme defined was 'Inward FDI' which is formed by the classes 'Innovative FDI' and 'Capital Flows'. Articles that deal specifically with the relationship between FDI and innovation in emerging economies form the Innovative FDI class (Barros, 2015; Dechezlepretre et al., 2011; Gorodnichenko et al., 2008; Liu et al., 2010). Consideration is given to patent registration in emerging economies, technical efficiency, open innovation, and technological spillover, especially in sectors such as automotive, agribusiness, among others. Technological spillover contributes to facilitate the expansion of innovation benefits to other local firms and subsidiary of the MNE and is underscored by absorptive capacity and technology diffusion (Anwar \& Nguyen, 2011; Sabirianova et al., 2005).

Of particular note, the emerging economies are no longer seen merely as recipients of innovations but also as generators of incremental and radical innovation and technological spillover, marking a new trend in IB (Jiang et al., 2011; Marin \& Sasidharan, 2010). Under this cluster, we also observed that MNEs engaged in innovation and collaborating in emerging economies tend to patent innovations more than firms not engaged in innovation, despite the weaknesses that often attach to the local patent system, as highlighted by Barros (2015).

Other research on the spillover of MNEs in India has highlighted the significant technical efficiency of foreign companies compared to local companies, which ultimately benefited from technological learning (Sur et al., 2018). Domestic (local) companies can effectively benefit from FDI that promotes technological spillovers. From an organizational learning standpoint, home businesses can benefit from this spillover and improve their productivity (Huang et al., 2017; Nyuur et al., 2016; Xie \& Li, 2017).

This situation tends to be favored especially if the foreign company has low export intensity, intangible assets, and a more rhythmic and less irregular entry mode, which would allow a lower imitation barrier on the part of domestic companies (Zhang et al., 2014). Domestic companies in host countries can also take advantage of FDI technology spillovers from foreign MNEs and from a bigger range of innovative technologies and practices, especially if FDI originates from diverse MNEs (Zhang et al., 2010).

Domestic companies in emerging economies can be recipients of knowledge in a spillover relationship with IFDI. However, this depends on the ability and motivation of domestic companies in emerging economies to learn. Emerging economies like India have encouraged IFDI with technological diffusion, so that their domestic companies can capture the benefits of technological spillover. The essential condition for domestic companies in emerging economies to benefit from the IFDI spillover is to have at least reached an "intermediate" level of technological development. This helps domestic companies to have sufficient absorptive capacities to seek and combine new knowledge, obtained through IFDI, with their own local technologies and practices. This is especially possible where IFDI spread in emerging countries facilitate domestic companies being exposed to a variety of technologies and foreign management practices (Barros, 2015; Dechezlepretre et al., 2011; Gorodnichenko et al., 2008; Liu et al., 2010). 
The second class within the Inward FDI theme denoted 'Capital flows' includes the work by Broto et al. (2011) who analyzed the determinants of volatility of various types of capital inflows in emerging economies. In this work, they identified that there are difficulties that policy makers face in stabilizing capital flows. Thus, since 2000 global factors beyond the control of emerging economies have become increasingly significant in relation to country-specific factors and have grown in importance as determinants of capital flow volatility in recent years.

Emerging economies are characterized by high volatility and this is reflected in their respective value chains. In this sense, FDI in emerging economies tends to seek greater geographic diversification, since the high volatility expresses the macroeconomic risk inherent in the local context, which may involve, for example, balance of payments deficit, exchange rate devaluation, fiscal risk, inflation and oftentimes a lack of legal certainty. At the company level, the guarantee of corporate governance through independent and transparent boards tends to attract foreign investors, to the detriment of family businesses where this tends not to happen.

It is important to note that it is not only the low cost of labor in emerging economies that attracts the FDI, but also the possibility of harnessing local skills and increasing knowledge about these contexts (e.g., Norwegian MNEs in Lithuania). However, emerging economies are not always able to take advantage of the FDI for its industrialization and rapid growth, as there can be a lack of absorptive capacity (Aizenman \& Binici, 2016; Johanson \& Vahlne, 1977; Luo \& Tung, 2007; Mathews, 2006; Mimouni \& Temimi, 2018; Rao \& Reddy, 2015; Razin et al., 1999; Wouters \& Van Kerckhoven, 2017).

In addition to the authors cited, capital flows were also studied by Agosin and Huaita (2011), Aizenman and Binici (2016), Chari et al. (2012), Humanicki et al. (2013), Li and Rajan (2015), MacDonald (2015), Sula and Willet (2009), Vo et al. (2017). Other topics of particular focus in this class include the impact of financial crises on emerging economy FDI flows (Aizenman \& Binici, 2016; Mimouni \& Temimi, 2018; Rao \& Reddy, 2015; Razin et al., 1999; Vo, 2018; Wouters \& Van Kerckhoven, 2017); the choice between direct and indirect portfolio investments (Butler \& Joaquin, 1998; Frot \& Santiso, 2013; Kemme et al., 2014; MacDonald, 2015) and investment-related macroeconomic volatility (Aizenman, 2002; Beaulieu et al., 2005; Epaulard \& Pommeret, 2016).

The second theme identified in our analysis is 'Outward FDI from Emerging Countries', which is also composed of two classes, namely the 'Institutional Environment' and the 'Theoretical Framework of FDI'. In the 'Institutional Environment' class, we observe the agglomeration of codes related to the location of the FDI in emerging economies. Due to the turbulent environment of these countries, FDI is seen to use local diversification to mitigate risks, as well as consider corporate governance practices (mechanisms to prevent corruption) and ways to facilitate control and minimize transaction costs (He et al., 2016; Qunyong, 2017; Ray et al., 2018). Institutional distance also features in the investment decision and the allocation of FDI to the emerging economy (Arslan et al., 2015; Dikova et al., 2016; Hernández et al., 2018). 
It is not uncommon for OFDI to be based on a reactive reason to flee local conditions, marked by an unstable institutional environment. In this context, EMNEs benefit from the FDI to leverage international connections and their local business ties of relevance for internationalization. This can be easily seen in the importance of commitment between partners for an entry involving an international joint venture. When considering IFDI and OFDI in emerging economies, it is crucial to integrate the institutional vision and local business ties into alliances as an international joint venture. The evolution of subsidiaries in emerging economies, on the other hand, depends on the ability to mobilize knowledge creation and the local knowledge network (Buckley et al., 2007; Child \& Rodrigues, 2005; He et al., 2016; Qunyong, 2017; Ray et al., 2018; Yao \& Zhou, 2019).

In their survey of 1610 subsidiaries of Japanese companies from 1979 to 2003, Ma and Delios (2007) noted that Japanese MNEs tend to choose economy-oriented cities (Shanghai) rather than policy-oriented cities (Beijing) in their FDI allocations. This type of FDI's location criterion helped Japanese MNEs avoid uncertainty in emerging economies, as in for example the Chinese case.

It also signals that analysis of the sub-national level of the institutional environment is relevant to the decision surrounding FDI location in the emerging economy. Institutional theories and resource-based views, for example, have proven important theoretical levers for understanding why Taiwan-based business groups legitimize and support the decisions and initiatives of their subsidiary affiliates in China to enable greater adaptability to local conditions and thus increase the chances of success of the FDI (Lin, 2016; Lu \& Ma, 2008).

There is a preference for the governance model of the MNE's country of origin, compared to the local governance model of emerging economies. This is because the institutional environment in emerging economies is typically less mature. When considering emerging economies as the target of FDI, MNEs from developed countries consider the insider shareholding to be relevant in the selection of local partners. This is due to the fact that the smaller the institutional distance between the emerging economies and the developed countries, for example, the smaller the LOF becomes. If the institutional distance is high, then the investor will want to have greater control in terms of the target company's shares. This is also in line with internalization theory, in the sense of mitigating the effects of transaction costs. Thus, particular emphasis is placed on the idea that institutional aspects are central to the survival of the international subsidiary, whether in the case of IFDI or in the case of OFDI (Arslan et al., 2015; Dikova et al., 2016; He et al., 2016; Hernández et al., 2018; Lu et al., 2015; Luo et al., 2009; Qunyong, 2017; Ray et al., 2018).

The second class within the Outward FDI from Emerging Countries theme labeled 'Theoretical Framework of FDI' discusses the suite of different theories and approaches used in FDI research in emerging economies. According to Klimek (2015) when companies from emerging economies start to have their own MNEs, then the validity of the internationalization theories of developed countries will be questioned for this new situation. Therefore, this cluster suggests that new theoretical insights arising from the actions and the activities of MNEs from emerging economies engaged in outward FDI are important and necessary in order to balance the body of knowledge. 
The novelty of the late comer perspective, which suggests that traditional internationalization theories are less applicable to MNEs in emerging economies is an important thread in this work on theoretical frameworks (Satta et al., 2014). It has been argued that to understand emerging economies internationalization experiences and their respective outward FDI, a longitudinal approach built around multiple levels of analyses, with both institutional and resource-dependency theories serving as theoretical lenses, have been proposed as an approach which could yield particularly valuable insights (Deng, 2013; Peng, 2001). Several dynamics seem to pertain to emerging market outward FDI decisions. Strategic foreign market networks and disregard for psychic distance given the geographic diversification that characterizes outward FDI flows from emerging economies (Ryan et al., 2018; Satta et al., 2014), along with the sense of risk and the fear of internationalization (Ramsey et al., 2016) all appear to be significant for emerging economies, especially in times of crisis. According to Enderwick (2017), an additional striking feature of emerging economies relates to institutional voids which are market facilitating institutions that are either absent, or not functioning effectively and which typically result in increased levels of uncertainty and transaction costs.

The third and final theme emanating from our thematic content analysis relates to debates and contributions to the literature focused on 'Location Choice'. FDI entry strategies in emerging economies can be riskier or more conservative, depending on the level of commitment being made. Developed countries generally prefer acquisition strategies or joint ventures to mitigate perceived risks inherent in the institutional environments of emerging economies. Scholars in particular have called attention to situations in which strategies involving greater delegation and autonomy being afforded to subsidiaries are pursued. The underlying motive for this approach centers on affording the subsidiaries opportunities to learn and to better adapt their products and services with a view to generating gains for the parent (Chiao et al., 2010; Wang et al., 2014). Market-seeking FDI tends to be more sensitive to the heterogeneities that exist between markets and institutions in emerging as opposed to developed economies than does resource-seeking FDI. As a result, contributions that debate the most appropriate FDI entry mode into emerging economies abound. And in this debate, it is evident that institutional aspects have a considerable effect on the choice of entry mode and especially the strategy to be adopted ( $\mathrm{Lu}$ et al., 2014). Market-driven companies have a sharp focus on the host country's institutional environment (Pan, 2017). It has been shown that to mitigate some of the risks and uncertainties in the institutional environment of emerging economies, Finnish MNEs, as a case in point, tend to pursue a cost leadership strategy to secure concrete competitive advantages over competitive rivals in these markets (Larimo \& Nguyen, 2015).

Recent patterns of internationalization of EMNEs have raised increasing interest in their motivators. When looking at the Chinese OFDI for example, the institutional environment is the determining factor in attracting this type of OFDI. EMNEs tend to seek developed countries to carry out the FDI, in view of the institutional strength and stability of these countries, in a strategy known as "institutional substitution" in relation to the country of origin, in addition to seeking access to knowledge. In this sense, EMNEs tend to pursue "institutional diversification" more as a hedge 
against shocks from their own countries of origin and less for the traditional reasons of seeking assets in developed markets.

Regarding the IFDI, cultural distance negatively impacts some of the efforts at global standardization by MNEs from developed countries. This signals that the IFDI is also subject to the LOF when it proposes to enter an emerging economy (Hoskisson et al., 2000; Peng et al., 2008; Meyer et al., 2009).

Of note, in the emerging economies context institutional pressures may also stem from home country governments. Thus, for example, in the case of Chinese MNEs, the drive towards international joint ventures serves to mitigate some of the dependence on Government resources. This stands in contrast to some developed countries that tend to have stable institutional environments, lower FDI risks and that are seen to be somewhat freer from these institutional pressures (Luiz et al., 2017).

Insights from economic geography increasingly call attention to the fact that the performance of subsidiaries can be affected by the characteristics of the sub-national regions and not just the country. At the macro level, this implies that understanding institutional distance needs to go beyond measures between countries, such as stocks and flows of foreign direct investment, and begin to incorporate variations within the country, while developing a more accurate theory about the effects of space. At the micro level, this implies that the effects of clustering and agglomeration, the thickness of local connections and the nature of connections may be important contributors to meaning (Beugelsdijk et al., 2010; Beugelsdijk \& Mudambi, 2013; Lu et al., 2019).

Distinguishing country level (macro) and firm level (micro) influences also serves to generate critical insights. In terms of country level, as seen in the results, it is crucial to consider macroeconomic aspects first, which may cause volatility in global value chains. These aspects involve macroeconomic prices, such as the inflation rate, the exchange rate, the interest rate, and the country's fiscal risk, along with the balance of payments. Exchange rate devaluation, for example, can be a particular feature of emerging economies, which makes it difficult to import industrial components and which increases production costs. Institutional risk is also added, involving political and regulatory instability, which can compromise the FDI and its long-term return. This tends to explain why OFDI from emerging economies tends to prioritize countries with institutional stability. Importantly, OFDI from emerging economies also faces the LOF identified earlier among developed economy MNEs and this tends to hinder and increase the internationalization process and costs for EMNEs. Furthermore, from a macro perspective, emerging economies tend to have significant regional inequities and heterogeneities in terms of infrastructure, resources and business networks that can influence FDI performance with the result that a greater subnational emphasis may be demanded.

In terms of micro level, domestic companies do not always have the absorptive capabilities necessary to take advantage of technological spillovers from FDI. The level of corporate governance is also not usually mature and impartial, compromising management transparency. In addition, local knowledge networks are essential to increase the performance of subsidiaries. At this level, attention to the subnational context also becomes relevant, since regional differences in institutional and economic terms can influence the FDI's performance. Aspects of the subnational 
context such as the attractiveness of the market, the size of the market, human capital and socioeconomic development become relevant for FDI decisions. As an example of an FDI subnational context analysis Stallkamp et al., (2018) highlight that peripheral regions in emerging economies are rich in valuable resources such as semi-skilled labor and this would be a comparative advantage relative to central regions of an emerging economy. In this way there is a need to look at the idiosyncrasies of emerging economies and to analyze the subnational context for FDI decisions and bring fuller insights into the interaction between place, space, and organization (Beugelsdijk et al., 2010).

\section{Opportunities for Future Research}

Described as a 'portmanteau term' (Horwitz et al., 2015, p. 470), the label 'emerging economies' is built on a series of layered insights garnered from several academic fields and multiple levels of analysis. Originally coined in the 1980s, albeit with several earlier linked terminologies, the literature is evolving and diverse. The body of scholarly work specifically focused on MNEs and emerging economy inward and outward FDI is dispersed across a wide range of domain areas and journals and is characterized by diversity with respect to the theoretical lenses employed, the levels of analysis examined, and the knowledge generated. Its importance in the IB context should not be underestimated. Poór et al. (2014) note that the ratio of people employed by MNEs is significantly higher in many transitional economies than in most Western ones, making them powerful, if sometimes "ambiguous" actors in these locations (Cooke et al., 2011, p. 371), with many MNEs playing a direct part in the very construction of the environment in which they operate. Much has been documented and achieved to date in furthering our understanding of MNEs and the ebb and flow of FDI in emerging economies. As an area of inquiry, the field has been on an upward trajectory since 1990 onwards and has achieved momentum in terms of the increasing volume and impact of published output in the past decade. Against this backdrop, our purpose in this article has been to bring greater systematics to this evolving field through mapping its contours and intellectual structure. Arising from the contributions made to-date, we see a number of opportunities for future research. In what follows, we call attention to three indicative particular research paths and suggest possible sample questions linked with the domain areas spotlighted.

\section{Opportunity 1: Greater Context Informed Theorization}

In many ways, the emerging economies represent, in relative terms, something of a "new frontier for academics and practitioners alike", but one which offers a series of academic opportunities, encompassing not just the empirical and the analytical but perhaps more fundamentally the theoretical (Horwitz et al., 2015, p. 470). There is a theoretical imbalance in the body of scholarship to-date. Emerging economies are characterized by different contextual endowments and an important question that has emerged is the extent to which 'Western theories' and 'best practices' are relevant and can been applied in these contexts. Importantly also, the range of contexts 
of relevance regarding the debate on both IFDI into emerging economies and OFDI from emerging economies is becoming increasing heterogenous. The effort at developing deeper contextual insights in order to make new theoretical contributions deserves additional scholarly attention, given the significance and diversity of many of these economies. The reality is that they are underscored by complex political, economic and social dynamics, a deeper appreciation of which is important in our overall theorizing effort.

With their increasing internationalization, we see new opportunities for contextually informed theories on emerging economy FDI led by scholars from the emerging economies and based on local, legitimate, and important ideas which could serve to augment existing, largely western theories. Insights from the emerging economies centrally involving local authors offers the prospect of the curation of a wider range of contextual knowledge that has important local legitimacy and that, properly situated and employed, may assist MNEs in their internationalization into or from these territories. The recognition and inclusion of local conditions, both national and subnational given the scale and heterogeneity inherent in many emerging economies, and the spotlighting of lesser explored variables of relevance in that context could serve to consolidate concepts that really do enhance our understanding of idiosyncratic elements of the institutional environments of emerging countries. The establishment of collaborative networks involving local scholars in leading the theorizing effort and in the co-creation of the knowledge could prove fruitful. Morley and Heraty (2019) have recently argued that academic collaboration via international cooperative research networks is becoming more common in business scholarship, something which they suggest can be read in at least two ways. From a philosophical perspective, they suggest that the emergence of these networks can be viewed as a fundamental effort towards enhancing theory building and deepening our understanding of practices in an era in which the domain of business research has become more international. From an historical perspective, they argue that the increasing prevalence and importance of collaborative networks lies in the fact that they are particularly important conduits to more fully landscaping the many contextual features of business practice in numerous territories that have not been fully incorporated into the body of knowledge. Collaborative networks focused on contextually informed fundamental theory development should prove particularly valuable in augmenting and rebalancing the body of evidence on emerging economies, plugging research gaps, and unearthing and giving expression to indigenous features that characterize practice in many of these contexts. Overall, therefore the importance of the local national and sub-national settings in terms of path dependence and macroeconomic aspects is significant in seeking to understand the diversity of experiences surrounding emerging economy FDI and this context heterogeneity offers the prospect of serving as a rich source of theorizing. Examples of research questions of relevance here could include: 
- What theoretical lenses explicate management practice variations between EMNEs and developed economy MNEs?

This research question is linked with analyses focused on managerial practices related to psychic distance between developed and emerging economies, choice of entry modes, diversification and performance of MNEs in emerging economies (Tihanyi et al., 2005). However, to a certain extent there is a unilateral interpretation based on already consolidated frameworks of the MNEs of developed economies, which silence the adaptations and adjustments of the practices of the EMNEs. EMNEs seem not to emulate the same practices as MNEs in developed economies and their variations would need to be captured by theoretical lenses capable of filtering peculiarities of the practices of EMNEs in their original context. Theoretical lenses that consider path dependence (Kao et al., 2013; Kuo et al., 2012) are crucial to deepen the analysis of the variations in management practices in relation to the MNEs in developed economies.

- Do the EMNEs prefer more ethnocentric or geocentric management recipes in governing their geographically dispersed subsidiaries?

This research opportunity could serve to augment findings concerning the level of ownership capital by EMNEs in other countries. As mentioned in the Moderate FDI Cluster, the level of ownership capital by EMNEs in other countries tends to be higher where there is greater institutional distance between the emerging country and the host country (Kao et al., 2013; Kuo et al., 2012). There has been an emphasis on the institutional configuration of the host country as a determining element in OFDI by emerging economies (Luo et al., 2010). The institutional configuration of the host countries would dictate the geographical dispersion of OFDI, since EMNEs would be more interested in stable and institutionally complementary countries. Nevertheless, there is room for a fuller understanding of the management style of EMNEs concerning the type of relationship between their headquarters and their subsidiaries and the level of autonomy afforded to subsidiaries (Wang et al., 2014). Research that investigates not only the flow of OFDI from emerging economies and its geographical dispersion, but also the attendant management style would be especially relevant.

- Do EMNEs possess particular ownership advantages and how can we theorize them?

OFDI of EMNEs can benefit from an institutional network in the home country, combined with a technological capacity in $R \& D$, which is usually present in a competitive environment (Yiu et al., 2007). In investigating the ownership advantages and necessary actions that EMNEs need to take to expand internationally, doing so against the backdrop of the reality of each emerging economy may yield additional insights. Different levels of development and macroeconomic conditions may justify different degrees of importance for certain ownership advantages. Although home country networking, technological capacity and corporate entrepreneurship are widely cited (Yiu et al., 2007), there is a shortage of explanations, for example, about other ownership advantages, according to the subnational context (Stallkamp et al., 2018). Thus, theorizing about proprietary advantages without treating emerging economies as homogeneous units may prove illuminating. 


\section{Opportunity 2: Emerging Economy Internationalization Motives}

The last two decades have witnessed a surge of outward FDI by major emerging economies. Research work focused on aspects of China's approach, experience and performance has dominated and there is now a substantial body of research on the internationalization approaches of Chinese MNEs in growing their global footprint (Cooke et al., 2018). Critically however, internationalization motives and experiences differ between different types of emerging economies for reasons of their specific endowments, their unique developmental trajectories and their unique points of departure in entering the international arena. And while, relative to their developed counterparts, emerging economy MNEs in their efforts at internationalization share certain liabilities that arise from being latecomers to internationalization in common, they also face unique contextual barriers and entry mode choices, depending on their endowments and their location investment decision. Casting further light on these, most especially as new players emerge from more diverse territories, could serve to generate additional or augmented frameworks capturing the continuum of possibilities surrounding emerging economy outward FDI and its likely future trajectory. Potential research questions in this stream could include:

- How can the evolution of emerging economies change the logic underlying the most recent acquisitions made by EMNEs?

This research question arose from the observation that most of the citations around the underlying logic of the acquisitions made by EMNEs tend to emphasize the search for strategic resources, which these same EMNEs do not have in their home country. These strategic resources cannot be obtained through Joint Ventures but are usually acquired through mergers and acquisitions (Deng, 2009). However, while acquisitions made by EMNEs have been presented as the dominant means of accessing strategic resources, this may change as emerging economies evolve and develop. EMNEs that have achieved a significant degree of evolution may use acquisitions for reasons different from the literature. For instance, acquisitions could be a way to promote a brownfield over greenfield FDI so that EMNEs might overcome LOF and spread their influence.

- Are the internationalization standards adopted by emerging and advanced economy entities converging?

Our analysis of the literature dealing with internationalization patterns suggests that the interest of foreign players in local resources, market efficiency and institutional characteristics are prevalent in the approaches of developed and emerging economies (Meyer et al., 2009). However, there is a theoretical gap regarding the convergence of these internationalization patterns between EMNEs and MNEs from developed economies. Further insights into the route to internationalization of EMNEs in terms of LOF, Liability of Newness (LON) and entry mode could cast further light on these patterns.

- Are EMNEs more heterogenous than their advanced economy counterparts?

In our content analysis we observed that EMNEs operate in a volatile environment, with different institutional configurations, which result in competitive disadvantages in the global arena (Hu \& Cui, 2014; Luo et al., 2010; Sanfili- 
ppo, 2015). Nevertheless, EMNEs are described in international literature in a dispersed and generic way, often assuming a homogeneity in the approach that downplays diversity and country idiosyncrasies. It may be inferred by the different trajectories of emerging economies, especially relating to institutions, market efficiency and path dependence, that EMNEs would be more heterogeneous than their counterparts in advanced economies, though this requires further investigation.

- What characteristics will constitute the next wave of investments in emerging economies, particularly China?

Drawing from the most cited articles on FDI in emerging economies, especially in China (Deng, 2009; Luo et al., 2010; Yiu et al., 2007), the interests of foreign players in local strategic resources, has dominated the literature on IFDI in China. However, the evolution of the Chinese market economy, combined with the promising of greater transparency of its institutions and the increasing adoption of its currency, may offer new perspectives for IFDI. Meanwhile in other emerging economies, intangible resources (knowledge, expertise) in underexplored subnational contexts and the maturing of institutions also provide opportunities for new insights on IFDI and should be an interesting avenue for future research.

- To what extent does "institutional substitution" drive OFDI from Emerging Economies?

EMNEs have an appreciation for institutionally stable environments and tend to direct OFDI to these environments. The search for foreign markets with stable environments may offer the chance of complementing the strategies of the EMNEs or an institutional environment that will serve as a substitute for the original EMNEs' environment (Luiz et al., 2017; Luo et al., 2010; Meyer et al., 2009). Our analysis suggests that research that deepens the degree of relevance of "institutional substitution" or "institutional diversification" as drivers for EMNEs could prove valuable.

\section{Opportunity 3: Institutional Heterogeneity and Sub National Locations}

Linked with the previous point, institutional and regulatory regimes are on-going critical considerations in the making of investment decisions by MNEs in emerging economies, in particular as the range of location choices expands and are characterized by established and newly identified institutional voids (Khanna \& Palepu, 1997). As Khanna (2015, p. 185) convincingly puts it, the two words in the phrase 'emerging markets' need to be taken equally seriously whereby "markets are simply institutional arrangements that allow buyers and sellers to come together" and the 'emerging' is "the recognition of the incompleteness of such arrangements". It has been consistently demonstrated that MNEs often have a persistent concern about the likelihood of transaction costs increasing as a result of the existence of such voids.

While they are commonplace on the business landscape of emerging economies, their acuteness and impact can and does vary significantly from one context to another and a universal, 'one size fits all' response on the part of the MNE, regardless of the emerging market context, is unlikely to be successful. The emergence of 
new and more diverse territories as host locations for FDI bring unique conditions that must be understood. Recent research from Brenesa et al. (2019) points to the potential explanatory power of a configurational approach whereby different degrees and levels of institutional voids can be understood to affect the very organizational configurations that are necessary to securing performance in different emerging market contexts.

IB and economic geography have recently focused on types of geographic units to analyze the effects of location on the performance of subsidiaries. These efforts have highlighted differences within the host country that challenge the assumption of institutional homogeneity (Chan et al., 2010; Kafouros et al., 2015) and the application of the lens builds the argument for a focus on subnational regions as the geographical scope of business by subsidiaries in the host country (Qian et al., 2013; Yang, 2018). In this way, the interest of economic geography relates to the "L" dimension (location) of Dunning's eclectic paradigm that can be unzipped into "place" and "space" (Dunning \& Lundan, 2008). Location refers to the geographic unit of analysis and is not restricted to the country level (McCann, 2011).

This conceptualization of a sub-national region from a geographical perspective has particular resonance for studies of location and subsidiary development (Hsu et al., 2017). Subnational regions within a large economy are often heterogeneous in factors of production, institutions and agglomeration. This heterogeneity can provide subsidiaries with differentiated opportunities and restrictions that shape the cost and potential return of their business activities and, ultimately, lead to differences in performance. Therefore, the effects of the subnational region are important in explaining the variation in performance of MNEs and their subsidiaries (Peng \& Lebedev, 2017). Differences within the host country in terms of subnational regions create unique investment opportunities for MNEs and therefore influence their choice of international location for subsidiaries (Alcácer et al., 2015). Increasingly therefore IB surveys on emerging economies are highlighting the importance of explaining subnational institutional variations (Lu et al., 2019). The FDI policies' variation within the host country may also result from differences in the implementation of state rules in subnational regions. Although these policies are defined at the level of the host country, their implementation generally occurs at the regional level. When competing for a share of FDI, regional governments differ in the way they implement policies to attract tax incentives and tariff reductions (Gaur et al., 2007). This variation in regional policy within the country affects not only inflows of FDI, but also the costs of doing business in different regions (Chan et al., 2010). Examples of research questions of relevance here could include:

- What governs the location choice of EMNEs?

The locational choices of EMNEs are usually categorized with the same logic as MNEs in developed economies, such as the search for stable institutional environments, efficient markets, strategic resources, and minor psychic distance. However, there is a theoretical gap concerning the driving forces underpinning the location choice of EMNEs' OFDI, which may differ from MNEs in advanced economies. Evidence heretofore points to institutional substitution, infrastructure, access to raw material, transportation costs, quality of work, political and 
social conditions among others (Borin \& Mancini, 2016; Deng, 2009; Hernández et al., 2018; Luo et al., 2010; Yang et al., 2013; Yiu et al., 2007) that govern the location choice of MNEs from advanced economies. However, one cannot easily categorize EMNEs simply as resource-seeking or market-driven entities.

- What are the reasons for EMNEs to invest in other emerging economies?

EMNEs do not always seek developed countries and there are factors in other emerging economies that can prove attractive. Thus, the OFDI from emerging economies that flows to other emerging economies may be in search of rare local resources, where there is a certain institutional stability and market efficiency (Meyer et al., 2009). Our analysis suggests that emerging economies can serve as environments for potential technological spillover and learning contributions. There is also the possibility of contributing to the environmental issue, which may prove a high potential for innovation (Brandl et al., 2021; Fatima, 2017; Zhou et al., 2019).

- Do EMNEs still prefer more risky host countries?

EMNEs can benefit from more risky host countries, as long as EMNEs can overcome local challenges such as regulators, customers and competitors. Risky environments may address high volatility and macroeconomic challenges such as inflation, unfavorable exchange rates, institutional instability, high interest rates and government fiscal risk (Hu \& Cui, 2014; Lu et al., 2015; Sanfilippo, 2015). However, by driving away other international competitors, these same risky environments can offer access to promising valuable resources in peripheral regions such as semi-skilled labor (Stallkamp et al., 2018) and result in institutional networks for those EMNEs that manage to survive in this context.

- How do subnational emerging market institutions affect the location choice of EMNEs?

It has been observed that aspects of the subnational context such as the attractiveness of the market, the size of the market, human capital and socioeconomic development may affect the FDI decision (Stallkamp et al., 2018). In this way, subnational emerging market institutions may vary in term of laws, tax regulation and market efficiency, which are relevant for location choice (Meyer et al., 2009; Hernández et al., 2018). Fuller accounts of how these same factors affect the EMNEs location choice in subnational emerging market institutions would be welcome.

- How do regulatory voids affect competitive advantage and OFDI?

Institutional homogeneity remains a significant thread in the literature and, though growing, more research on subnational regions as a geographical scope would be welcome (Chan et al., 2010; Kafouros et al., 2015; Qian et al., 2013; Yang, 2018). In this context, institutional voids related to the gaps and lack of articulation in local laws, involving central and peripheral regions may affect competitive advantage, in terms of legal certainty, patents, etc. (Deng, 2009; Luo et al., 2010; Meyer et al., 2009). The extent to which this might prove important in the attraction or otherwise of OFDI could also represent a relevant research opportunity. 


\section{Conclusion}

In this bibliometric we have mapped key elements of the intellectual structure of the body of work on inward and outward emerging economy FDI. Our co-citation of publication references reveals that the work comprising the field can be seen to be anchored around three predominant lines of inquiry, namely scholarship generating insights on the processes of internationalization, the dominant motives for internationalization and work focused on explicating the internationalization strategies pursued by MNEs. Our keywords network analysis provides additional opportunities for understanding the direction of travel of this evolving field. Here three particular subjects could be identified as being especially important for unraveling the nature and direction of the literature regarding MNE FDI. A "Conservative FDI" stream which is dominated by a traditional approach to FDI, a "Bold FDI" stream governed by work on MNE subsidiaries as platforms for innovation, and a "Moderate FDI" stream lead by work which calls attention to the importance of context and the value of a polycentric approach in the management of geographically dispersed operations. Finally, our thematic content analysis derived from text strata constituting the corpus of work revealed that knowledge and insight has been built around three key platforms. Firstly, a deal of evidence has been accumulated on 'Inward FDI' into the emerging economies, particularly centering around building cumulative knowledge on 'Capital Flows' and 'Innovative FDI'. Work in this genre has variously provided insights on timely topics such as FDI and innovation, the impact of financial crises on the FDI of emerging economies, the benefits of the FDI for domestic (local) companies and technological spillovers. The second area to emerge from our content analysis referred to 'Outward FDI' from the emerging economies, built around two focal areas of inquiry, namely understanding the effects of the 'Institutional Environment' and the relevance and explanatory power of particular 'Theoretical Frameworks" in explicating FDI preferences and patterns. Work in this tradition examined, among other things, institutional distance between countries and its impact on FDI, institutional voids and their consequences, along with the importance of local diversification in order to mitigate risks. The third significant thread identified in our thematic analysis relates to the topic of 'Location Choice'. In this domain area, work distinguishing whether particular emerging market host locations vary with respect to attendant risk is evident, along with work examining institutional pressures arising from home and host governments, and work detailing allied institutional considerations that, in combination, serve to significantly influence the nature and direction of the investment decision.

Overall, classical theories have been widely used to explain the experience of EMNEs, and much has been theoretically and empirically established. However, there is little doubt that opportunities exist for further theorization and landscaping of idiosyncratic contextual, structural, and functional aspects of emerging economies and their role and impact on the evolving contours of inward and outward FDI in these diverse contexts. 
Funding Open Access funding provided by the IReL Consortium.

Open Access This article is licensed under a Creative Commons Attribution 4.0 International License, which permits use, sharing, adaptation, distribution and reproduction in any medium or format, as long as you give appropriate credit to the original author(s) and the source, provide a link to the Creative Commons licence, and indicate if changes were made. The images or other third party material in this article are included in the article's Creative Commons licence, unless indicated otherwise in a credit line to the material. If material is not included in the article's Creative Commons licence and your intended use is not permitted by statutory regulation or exceeds the permitted use, you will need to obtain permission directly from the copyright holder. To view a copy of this licence, visit http://creativecommons.org/licen ses/by/4.0/.

\section{References}

Agosin, M. R., \& Huaita, F. (2011). Capital flows to emerging economies: Minsky in the tropics. Cambridge Journal of Economics, 35(4), 663-683. https://doi.org/10.1093/cje/beq047

Aizenman, J. (2002). Volatility, employment and the patterns of FDI in emerging markets $\left(\mathrm{N}^{\circ}\right.$ w9397; p. w9397). https://doi.org/10.3386/w9397

Aizenman, J., \& Binici, M. (2016). Exchange market pressure in OECD and emerging economies: Domestic vs. external factors and capital flows in the old and new normal. Journal of International Money and Finance, 66, 65-87. https://doi.org/10.1016/j.jimonfin.2015.12.008

Alcácer, J., Dezsô, C., \& Zhao, M. (2015). Location choices under strategic interactions. Strategic Management Journal, 36(2), 197-215. https://doi.org/10.1002/smj.2214

Amatucci, M., \& Avrichir, I. (2008). Teoria de negócios internacionais e a entrada de multinacionais no Brasil de 1850 a 2007. Revista Brasileira De Gestão De Negócios, 10(28), 234-248.

Anwar, S., \& Nguyen, L. P. (2011). Foreign direct investment and export spillovers: Evidence from Vietnam. International Business Review, 20(2), 177-193. https://doi.org/10.1016/j.ibusrev. 2010.11.002

Arslan, A., Tarba, S. Y., \& Larimo, J. (2015). FDI entry strategies and the impacts of economic freedom distance: Evidence from Nordic FDIs in transitional periphery of CIS and SEE. International Business Review, 24(6), 997-1008. https://doi.org/10.1016/j.ibusrev.2015.03.004

Ayme, F. G., Jr. (2003). Balance-of-payments-constrained economic growth in Brazil. Brazilian Journal of Political Economy, 23(1), 63-86. https://doi.org/10.1590/0101-31572004-0708

Bardin, L. (2011). Content Analysis. Sao Paulo: Edicoes: 70.

Barros, H. M. (2015). Exploring the use of patents in a weak institutional environment: The effects of innovation partnerships, firm ownership, and new management practices. Technovation, 45-46, 63-77. https://doi.org/10.1016/j.technovation.2015.05.003

Beaulieu, M.-C., Cosset, J.-C., \& Essaddam, N. (2005). The impact of political risk on the volatility of stock returns: The case of Canada. Journal of International Business Studies, 36(6), 701-718. https://doi.org/10.1057/palgrave.jibs.8400160

Beugelsdijk, S., McCann, P., \& Mudambi, R. (2010). Introduction: Place, space and organization- economic geography and the multinational enterprise. Journal of Economic Geography, 10(4), 485493. https://doi.org/10.1093/jeg/lbq018

Beugelsdijk, S., \& Mudambi, R. (2013). MNEs as border-crossing multi-location enterprises: The role of discontinuities in geographic space. Journal of International Business Studies, 44(5), 413-426. https://doi.org/10.1057/jibs.2013.23

Bhat S. A., Bhat J. A. (2021). Impact of Exchange Rate Changes on the Trade Balance of India: An Asymmetric Nonlinear Cointegration Approach. Foreign Trade Review, 56(1), 71-88. https://doi. org/10.1177/0015732520961328

Borin, A., \& Mancini, M. (2016). Foreign direct investment and firm performance: An empirical analysis of Italian firms. Review of World Economics, 152(4), 705-732. https://doi.org/10.1007/ s10290-016-0255-Z

Brandl, K., Moore, E., Meyer, C., \& Doh, J. (2021). The impact of multinational enterprises on community informal institutions and rural poverty. Journal of International Business Studies. https://doi. org/10.1057/s41267-020-00400-3 
Brenesa, E. R., Ciravegna, L., \& Pichardoa, C. A. (2019). Managing institutional voids: A configurational approach to understanding high performance antecedents. Journal of Business Research, 105, 345358. https://doi.org/10.1016/j.jbusres.2018.03.022

Broto, C., Díaz-Cassou, J., \& Erce, A. (2011). Measuring and explaining the volatility of capital flows to emerging countries. Journal of Banking \& Finance, 35(8), 1941-1953. https://doi.org/10.1016/j. jbankfin.2011.01.004

Buckley, P. J., Clegg, L. J., Cross, A. R., Liu, X., Voss, H., \& Zheng, P. (2007). The determinants of Chinese outward foreign direct investment. Journal of International Business Studies, 38(4), 499-518.

Butler, K. C., \& Joaquin, D. C. (1998). A note on political risk and the required return on foreign direct investment. Journal of International Business Studies, 29(3), 599-607. https://doi.org/10.1057/ palgrave.jibs.8490009

Chan, C. M., Makino, S., \& Isobe, T. (2010). Does subnational region matter? Foreign affiliate performance in the United states and China. Strategic Management Journal, 31(11), 1226-1243. https:// doi.org/10.1002/smj.854

Chari, A., Chen, W., \& Dominguez, K. M. E. (2012). Foreign ownership and firm performance: Emerging market acquisitions in the United States. IMF Economic Review, 60(1), 1-42. https://doi.org/ 10.1057/imfer.2012.1

Chiao, Y., Lo, F., \& Yu, C. (2010). Choosing between wholly-owned subsidiaries and joint ventures of MNCs from an emerging market. International Marketing Review, 27(3), 338-365. https://doi.org/ $10.1108 / 02651331011047998$

Child, J., \& Rodrigues, S. B. (2005). The internationalization of Chinese firms: A case for theoretical extension? Management and Organization Review, 1(3), 381-410. https://doi.org/10.1111/j.17408784.2005.0020a.x

Cooke, F. L., Wood, G., Psychogios, A. G., \& Szamosi, L. T. (2011). HRM in emergent market economies: Evidence and implications from Europe. Human Resource Management Journal, 21(4), 368378. https://doi.org/10.1111/j.1748-8583.2011.00181.x

Cooke, F. L., Wu, G., Zhou, J., Zhong, C., \& Wang, J. (2018). Acquiring global footprints: Internationalization strategy of Chinese multinational enterprises and human resource implications. Journal of Business Research, 93, 184-201. https://doi.org/10.1016/j.jbusres.2018.04.012

Danakol, S. H., Estrin, S., Reynolds, P., \& Weitzel, U. (2017). Foreign direct investment via M\&A and domestic entrepreneurship: Blessing or curse? Small Business Economics, 48(3), 599-612. https:// doi.org/10.1007/s11187-016-9792-Z

Dechezlepretre, A., Glachant, M., Hascic, I., Johnstone, N., \& Meniere, Y. (2011). Invention and Transfer of Climate Change-Mitigation Technologies: A Global Analysis. Review of Environmental Economics and Policy, 5(1), 109-130. https://doi.org/10.1093/reep/req023

Deng, P. (2009). Why do Chinese firms tend to acquire strategic assets in international expansion? Journal of World Business, 44(1), 74-84. https://doi.org/10.1016/j.jwb.2008.03.014

Deng, P. (2013). Chinese outward direct investment research: Theoretical integration and recommendations. Management and Organization Review, 9(3), 513-539. https://doi.org/10.1111/more.12030

Dikova, D., Panibratov, A., Veselova, A., \& Ermolaeva, L. (2016). The joint effect of investment motives and institutional context on Russian international acquisitions. International Journal of Emerging Markets, 11(4), 674-692. https://doi.org/10.1108/IJoEM-04-2016-0105

Ding, Y., Chowdhury, G. G., \& Foo, S. (2000). Journal as Markers of Intellectual Space: Journal CoCitation Analysis of Information Retrieval Area, 1987-1997. Scientometrics, 47(1), 55-73. https:// doi.org/10.1023/A:1005665709109

Ding, Y., Rousseau, R., \& Wolfram, D. (2014). Measuring scholarly impact. Springer.

Dunning, J. H., \& Lundan, S. M. (2008). Institutions and the OLI paradigm of the multinational enterprise. Asia Pacific Journal of Management, 25(4), 573-593. https://doi.org/10.1007/ s10490-007-9074-z

Enderwick, P. (2017). Viewpoint escape FDI from emerging markets: Clarifying and extending the concept. International Journal of Emerging Markets, 12(3), 418-426. https://doi.org/10.1108/ IJoEM-11-2016-0325

Epaulard, A., \& Pommeret, A. (2016). Financial integration, growth and volatility: Financial integration, growth and volatility. Pacific Economic Review, 21(3), 330-357. https://doi.org/10.1111/14680106.12177

Fatima, S. T. (2017). Globalization and technology adoption: Evidence from emerging economies. The Journal of International Trade \& Economic Development, 26(6), 724-758. https://doi.org/10.1080/ 09638199.2017.1303080 
Frot, E., \& Santiso, J. (2013). Political uncertainty and portfolio managers in emerging economies. Review of International Political Economy, 20(1), 26-51. https://doi.org/10.1080/09692290.2011. 625916

Gaur, A. S., Delios, A., \& Singh, K. (2007). Institutional environments, staffing strategies, and subsidiary performance. Journal of Management, 33(4), 611-636. https://doi.org/10.1177/0149206307 302551

Gorodnichenko, Y., Svejnar, J., \& Terrell, K. (2008). Globalization and innovation in emerging markets ( $\mathrm{N}^{\mathrm{o}}$ w14481; p. w14481). https://doi.org/10.3386/w14481

He, X., Eden, L., \& Hitt, M. A. (2016). Shared Governance: Institutional investors as a counterbalance to the state in state owned multinationals. Journal of International Management, 22(2), 115-130. https://doi.org/10.1016/j.intman.2016.01.004

Hernández, V., Nieto, M. J., \& Boellis, A. (2018). The asymmetric effect of institutional distance on international location: Family versus nonfamily firms. Global Strategy Journal, 8(1), 22-45. https://doi.org/10.1002/gsj.1203

Horwitz, F. \& Budhwar, P. (Eds.) (2015). Handbook of human resource management in emerging markets. Edward Elgar Publishing

Horwitz, F., Budhwar, P., \& Morley, M. J. (2015). Future trends in human resource management in emerging markets. In F. Horwitz \& P. Budhwar (Eds.), Handbook of Human Resource Management in Emerging Markets (pp. 470-488). Edward Elgar Publishing

Hoskisson, R. E., Eden, L., Lau, C. M., \& Wright, M. (2000). Strategy in Emerging Economies. The Academy of Management Journal, 43(3), 249-267. https://doi.org/10.2307/1556394

Hsu, C.-W., Chen, H., \& D’Arcy, C. (2017). Local conditions, entry timing, and foreign subsidiary performance. International Business Review, 26(3), 544-554. https://doi.org/10.1016/j.ibusrev.2016. 11.005

Hu, H. W., \& Cui, L. (2014). Outward foreign direct investment of publicly listed firms from China: A corporate governance perspective. International Business Review, 23(4), 750-760. https://doi.org/ 10.1016/j.ibusrev.2013.11.003

Huang, J., Chen, X., Huang, B., \& Yang, X. (2017). Economic and environmental impacts of foreign direct investment in China: A spatial spillover analysis. China Economic Review, 45, 289-309. https://doi.org/10.1016/j.chieco.2016.03.006

Humanicki, M., Kelm, R., \& Olszewski, K. (2013). Foreign direct investment and foreign portfolio investment in the contemporary globalized world: Should they be still treated separately? National Bank of Poland Working Paper No. 167. https://doi.org/10.2139/ssrn.2369231

Iamsiraroj, S. (2016). The foreign direct investment-economic growth nexus. International Review of Economics \& Finance, 42, 116-133. https://doi.org/10.1016/j.iref.2015.10.044

IMF. (2018). World Economic Outlook: Challenges to Steady Growth. International Monetary Fund.

Jiang, C. X., Yang, Q., Li, S., \& Wang, Y. (2011). The moderating effect of foreign direct investment intensity on local firms' intangible resources investment and performance implications: A case from China. Journal of International Management, 17(4), 291-302. https://doi.org/10.1016/j.intman.2011.03.001

Johanson, J., \& Vahlne, J.-E. (1977). The internationalization process of the firm-a model of knowledge development and increasing foreign market commitments. Journal of International Business Studies, 8(1), 23-32. https://doi.org/10.1057/palgrave.jibs.8490676

Kafouros, M., Wang, C., Piperopoulos, P., \& Zhang, M. (2015). Academic collaborations and firm innovation performance in China: The role of region-specific institutions. Research Policy, 44(3), 803817. https://doi.org/10.1016/j.respol.2014.11.002

Kao, M. S., Kuo, A., \& Chang, Y. C. (2013). How family control influences FDI entry mode choice. Journal of Management \& Organization, 19(4), 367-385. https://doi.org/10.1017/jmo.2013.23

Kemme, D. M., Nikolsko-Rzhevskyy, A., \& Mukherjee, D. (2014). Foreign capital, spillovers and export performance in emerging economies: Evidence from Indian IT firms: export performance in emerging economies. Review of Development Economics, 18(4), 681-692. https://doi.org/10.1111/ rode. 12111

Khanna, T. (2015). A case for contextual intelligence. Management International Review, 55(2), 181190. https://doi.org/10.1007/s11575-015-0241-z

Khanna, T., \& Palepu, K. G. (1997). Why focused strategies may be wrong for emerging markets. Harvard Business Review, 5(4), 41-51.

Klimek, A. (2015). Institutions and outward foreign direct investment. International Journal of Management and Economics, 46(1), 101-119. https://doi.org/10.1515/ijme-2015-0023 
Korinek, A. (2017). Regulating Capital Flows to Emerging Markets: An Externality View (N ${ }^{\mathrm{o}}$ w24152; p. w24152). https://doi.org/10.3386/w24152

Kuo, A., Kao, M. S., Chang, Y. C., \& Chiu, C. F. (2012). The influence of international experience on entry mode choice: Difference between family and non-family firms. European Management Journal, 30(3), 248-263. https://doi.org/10.1016/j.emj.2012.03.008

Larimo, J. A., \& Nguyen, H. L. (2015). International joint venture strategies and performance in the Baltic States. Baltic Journal of Management, 10(1), 52-72. https://doi.org/10.1108/BJM-12-2013-0189

Leydesdorff, L. (2005). Similarity measures, author cocitation analysis, and information theory. Journal of the American Society for Information Science and Technology, 56(7), 769-772. https://doi.org/ 10.1002/asi.20130

Li, J., \& Rajan, R. S. (2015). Do capital controls make gross equity flows to emerging markets less volatile? Journal of International Money and Finance, 59, 220-244. https://doi.org/10.1016/j.jimonfin. 2015.07.007

Lin, W.-T. (2016). FDI decisions and business-group insider control: Evidence from Taiwanese groupaffiliated firms investing in the Chinese market. Journal of World Business, 51(4), 525-533. https:// doi.org/10.1016/j.jwb.2016.01.003

Liu, X., Lu, J., Filatotchev, I., Buck, T., \& Wright, M. (2010). Returnee entrepreneurs, knowledge spillovers and innovation in high-tech firms in emerging economies. Journal of International Business Studies, 41(7), 1183-1197. https://doi.org/10.1057/jibs.2009.50

López-Fernández, M. C., Serrano-Bedia, A. M., \& Pérez-Pérez, M. (2016). Entrepreneurship and family firm research: A bibliometric analysis of an emerging field. Journal of Small Business Management, 54(2), 622-639. https://doi.org/10.1111/jsbm.1216

Lu, C.-C., Kuan, T.-H., \& Liu, C.-C. (2015). Effects of location diversification and corporate governance on multinational enterprises' financial performance and risk-taking: Evidence from Taiwanese enterprises. China \& World Economy, 23(5), 63-84. https://doi.org/10.1111/cwe.12128

Lu, J., Liu, X., Filatotchev, I., \& Wright, M. (2014). The impact of domestic diversification and top management teams on the international diversification of Chinese firms. International Business Review, 23(2), 455-467. https://doi.org/10.1016/j.ibusrev.2013.07.002

Lu, J. W., \& Ma, X. (2008). The contingent value of local partners' business group affiliations. The Academy of Management Journal, 51(2), 295-314. https://doi.org/10.2307/20159510

Lu, W., Saka-Helmhout, A., \& Piekkari, R. (2019). Adaptation of compensation practice in China: The role of sub-national institutions. Management \& Organization Review, 15(2), 235-267. https://doi. org/10.1017/mor.2019.16

Luiz, J., Stringfellow, D., \& Jefthas, A. (2017). Institutional complementarity and substitution as an internationalization strategy: The emergence of an African multinational giant: institutional complementarity and substitution. Global Strategy Journal, 7(1), 83-103. https://doi.org/10.1002/gsj.1143

Luo, X., Chung, C.-N., \& Sobczak, M. (2009). How do corporate governance model differences affect foreign direct investment in emerging economies? Journal of International Business Studies, 40(3), 444-467. https://doi.org/10.1057/jibs.2008.66

Luo, Y., \& Tung, R. L. (2007). International expansion of emerging market enterprises: A springboard perspective. Journal of International Business Studies, 38(4), 481-498. https://doi.org/10.1057/ palgrave.jibs. 8400275

Luo, Y., Xue, Q., \& Han, B. (2010). How emerging market governments promote outward FDI: Experience from China. Journal of World Business, 45(1), 68-79. https://doi.org/10.1016/j.jwb.2009.04. 003

Ma, X., \& Delios, A. (2007). A new tale of two cities: Japanese FDIs in Shanghai and Beijing, 19792003. International Business Review, 16(2), 207-228. https://doi.org/10.1016/j.ibusrev.2007.01. 009

MacDonald, M. (2015). Patterns of international capital flows and productivity growth: New evidence: international capital flows and productivity. Review of International Economics, 23(5), 846-872. https://doi.org/10.1111/roie.12191

Marin, A., \& Sasidharan, S. (2010). Heterogeneous MNC subsidiaries and technological spillovers: Explaining positive and negative effects in India. Research Policy, 39(9), 1227-1241. https://doi. org/10.1016/j.respol.2010.06.001

Mathews, J. A. (2006). Dragon multinationals: New players in 21st century globalization. Asia Pacific Journal of Management, 23(1), 5-27. https://doi.org/10.1007/s10490-006-6113-0

McCain, K. W. (1990). Mapping authors in intellectual space: A technical overview. Journal of the American Society for Information Science, 41, 433-443. 
McCann, E. (2011). Urban policy mobilities and global circuits of knowledge: Toward a research agenda. Annals of the Association of American Geographers, 101(1), 107-130. https://doi.org/10.1080/ 00045608.2010 .520219

Merigó, J. M., Cancino, C. A., Coronado, F., \& Urbano, D. (2016). Academic research in innovation: A country analysis. Scientometrics, 108(2), 559-593. https://doi.org/10.1007/s11192-016-1984-4

Meyer, K. E., Estrin, S., Bhaumik, S. K., \& Peng, M. W. (2009). Institutions, resources, and entry strategies in emerging economies. Strategic Management Journal, 30(1), 61-80. https://doi.org/10.1002/ smj. 720

Mimouni, K., \& Temimi, A. (2018). What drives energy efficiency? New evidence from financial crises. Energy Policy, 122, 332-348. https://doi.org/10.1016/j.enpol.2018.07.057

Modou, D., \& Yun, L. H. (2017). An empirical investigation of causal relationship of Chinese FDI to African economies. International Journal of Academic Research in Business and Social Sciences, 7(3), 199-207.

Morley, M. J., \& Heraty, N. (2019). The anatomy of an international research collaboration: Building cumulative comparative knowledge in human resource management. International Studies of Management \& Organization, 49(4), 341-354. https://doi.org/10.1080/00208825.2019.1646485

Neumayer, E., Nunnenkamp, P., \& Roy, M. (2016). Are stricter investment rules contagious? Host country competition for foreign direct investment through international agreements. Review of World Economics, 152(1), 177-213. https://doi.org/10.1007/s10290-015-0231-Z

Nielsen, B. B., Asmussen, C. G., \& Weatherall, C. D. (2017). The location choice of foreign direct investments: Empirical evidence and methodological challenges. Journal of World Business, 52(1), 62-82. https://doi.org/10.1016/j.jwb.2016.10.006

Nyuur, R. B., Ofori, D. F., \& Debrah, Y. A. (2016). The impact of FDI inflow on domestic firms' uptake of CSR activities: The moderating effects of host institutions. Thunderbird International Business Review, 58(2), 147-159. https://doi.org/10.1002/tie.21744

OECD. (2015). Measuring International Investment by Multinational Enterprises. OECD Publishing.

Pan, Y. (2017). Strategic motives, institutional environments, and firm's FDI ownership. Multinational Business Review, 25(4), 307-327. https://doi.org/10.1108/MBR-11-2016-0041

Peng, M. W. (2001). The resource-based view and international business. Journal of Management, 27(6), 803-829. https://doi.org/10.1177/014920630102700611

Peng, M. W., \& Lebedev, S. (2017). Intra-national business (IB). Asia Pacific Journal of Management, 34, 241-245. https://doi.org/10.1007/s10490-017-9507-2

Peng, M. W., Wang, D. Y. L., \& Jiang, Y. (2008). An institution-based view of international business strategy: A focus on emerging economies. Journal of International Business Studies, 39(5), 920-936.

Pinto, P. M., \& Zhu, B. (2009). Fortune or Evil? The Effect of Inward Foreign Direct Investment on Corruption. International Studies Quarterly, 60(4), 693-705. https://doi.org/10.2139/ssrn.1324750

Poór, J., Karoliny, Z., Dobrai, K., Slavic, A., Kerekes, K., Farkas, F., \& Engle, A. D. (2014). Factors influencing human resource management solutions at subsidiaries of multinational companies in Central and Eastern Europe. Journal of East-West Business, 20(2), 93-119. https://doi.org/10. $1080 / 10669868.2014 .897288$

Qian, G., Li, L., \& Rugman, A. (2013). Liability of country foreignness and liability of regional foreignness: Their effects on geographic diversification and firm performance. Journal of International Business Studies, 44(6), 635-647. http://www.jstor.org/stable/23434212

Qunyong, X. (2017). Inward joint venture experience and entry mode choice of Chinese firms abroad: The moderating roles of CEO power. International Journal of Emerging Markets, 12(3), 488-507. https://doi.org/10.1108/IJoEM-03-2016-0079

Ramsey, J. R., Barakat, L., Mitchell, M. C., Ganey, T., \& Voloshin, O. (2016). The effects of past satisfaction and commitment on the future intention to internationalize. International Journal of Emerging Markets, 11(2), 256-272. https://doi.org/10.1108/IJoEM-06-2013-0097

Rao, N. V., \& Reddy, K. S. (2015). The impact of the global financial crisis on cross-border mergers and acquisitions: A continental and industry analysis. Eurasian Business Review, 5(2), 309-341. https://doi.org/10.1007/s40821-015-0028-y

Ray, S., Mondal, A., \& Ramachandran, K. (2018). How does family involvement affect a firm's internationalization? An investigation of Indian family firms. Global Strategy Journal, 8(1), 73-105. https://doi.org/10.1002/gsj.1196 
Razin, A., Sadka, E., \& Yuen, C.-W. (1999). An Information based model of foreign direct investment: The gains from trade revisited. International Tax and Public Finance, 6(4), 579-596. https://doi. org/10.1023/A:1008709617617

Reinert, M. (1990). Alceste une méthodologie d'analyse des données textuelles et une application: Aurelia De Gerard De Nerval. Bulletin of Sociological Methodology/bulletin De Méthodologie Sociologique, 26(1), 24-54. https://doi.org/10.1177/075910639002600103

Ruas, T. L., \& Pereira, L. (2014). Como construir indicadores de Ciência, Tecnologia e Inovação usando Web of Science, Derwent World Patent Index, Bibexcel e Pajek? Perspectivas Em Ciência Da Informação, 19(3), 52-81. https://doi.org/10.1590/1981-5344/1678

Ryan, P., Giblin, M., Andersson, U., \& Clancy, J. (2018). Subsidiary knowledge creation in co-evolving contexts. International Business Review, 27(5), 915-932. https://doi.org/10.1016/j.ibusrev.2018.02. 003

Sabirianova, K., Svejnar, J., \& Terrell, K. (2005). Distance to the efficiency frontier and foreign direct investment spillovers. Journal of the European Economic Association, 3(2-3), 576-586. https:// doi.org/10.1162/jeea.2005.3.2-3.576

Sanfilippo, M. (2015). FDI from emerging markets and the productivity gap-An analysis on affiliates of BRICS EMNEs in Europe. International Business Review, 24(4), 665-676. https://doi.org/10. 1016/j.ibusrev.2014.11.005

Satta, G., Parola, F., \& Persico, L. (2014). Temporal and spatial constructs in service firms' internationalization patterns: The determinants of the accelerated growth of emerging MNEs. Journal of International Management, 20(4), 421-435. https://doi.org/10.1016/j.intman.2014.05.001

Stallkamp, M., Pinkham, B. C., Schotter. A. P. J., Buchel, O. (2018). Core or periphery? The effects of country-of-origin agglomerations on the within-country expansion of MNEs. Journal of International Business Studies, 49(8), 942-966. https://doi.org/10.1057/s41267-016-0060-x

Sula, O., \& Willett, T. D. (2009). The reversibility of different types of capital flows to emerging markets. Emerging Markets Review, 10(4), 296-310. https://doi.org/10.1016/j.ememar.2009.08.001

Sur, A., Nandy, A., \& Zhang, X. (2018). FDI, technical efficiency and spillovers: Evidence from Indian automobile industry. Cogent Economics \& Finance, 6(1), 1460026. https://doi.org/10.1080/23322 039.2018.1460026

Tihanyi, L., Griffith, D., \& Russell, C. (2005). The Effect of cultural distance on entry mode choice, international diversification, and MNE performance: a meta-analysis. Journal of International Business Studies, 36(3), 270-283. https://doi.org/10.1057/palgrave.jibs.8400136

van Eck, N. J., \& Waltman, L. (2014). Visualizing Bibliometric Networks. In Y. Ding, R. Rousseau, \& D. Wolfram (Eds.), Measuring Scholarly Impact (p. 285-320). Springer. https://doi.org/10.1007/ 978-3-319-10377-8_13

van Leeuwen, T. (2006). The application of bibliometric analyses in the evaluation of social science research. Who benefits from it, and why it is still feasible? Scientometrics, 66(1), 133-154. https:// doi.org/10.1007/s11192-006-0010-7

van Leeuwen, T. N., Visser, M. S., Moed, H. F., Nederhof, T. J., \& van Raan, A. F. J. (2003). The Holy Grail of science policy: Exploring and combining bibliometric tools in search of scientific excellence. Scientometrics, 57(2), 257-280. https://doi.org/10.1023/A:1024141819302

van Raan, A. F. J. (2005). For Your Citations Only? Hot Topics in Bibliometric Analysis. Measurement: Interdisciplinary Research \& Perspective, 3(1), 50-62. https://doi.org/10.1207/s15366359m ea0301_7

Vo, X. V. (2018). Determinants of capital flows to emerging economies-Evidence from Vietnam. Finance Research Letters, 27, 23-27. https://doi.org/10.1016/j.frl.2018.02.031

Vo, X. V., Nguyen, D. P., Ho, V. T., \& Nguyen, T. T. (2017). Where do the advanced countries invest? An investigation of capital flows from advanced countries to emerging economies. Journal of International Financial Markets, Institutions and Money, 51, 142-154. https://doi.org/10.1016/j.intfin. 2017.09.004

Wang, S. L., Luo, Y., Lu, X., Sun, J., \& Maksimov, V. (2014). Autonomy delegation to foreign subsidiaries: An enabling mechanism for emerging-market multinationals. Journal of International Business Studies, 45(2), 111-130. https://doi.org/10.1057/jibs.2013.40

White, H. D., \& Griffith, B. C. (1981). Author cocitation: A literature measure of intellectual structure. Journal of the American Society for Information Science, 32(3), 163-171. https://doi.org/10.1002/ asi.4630320302

White, H. D., \& McCain, K. W. (1998). Visualizing a discipline: An author co-citation analysis of information science, 1972-1995. Journal of the American Society for Information Science, 49(4), 
327-355. https://doi.org/10.1002/(SICI)1097-4571(19980401)49:4\%3C327::AID-ASI4\%3E3.0. $\mathrm{CO} ; 2-4$

World Bank. (2019). Global Economic Prospects: Darkening skies. World Bank Group.

Wouters, J., \& Van Kerckhoven, S. (2017). The G20 and the BRICS on Trade and Investment: Trends and Policies. International Organizations Research Journal, 12(3), 7-31. https://doi.org/10.17323/ 1996-7845-2017-03-7

Xie, Z., \& Li, J. (2017). Export intensity, domestic competition, and product innovation in an emerging economy. International Journal of Technology Management, 74(1-4), 96-121. https://doi.org/10. 1504/IJTM.2017.083612

Yang, J. (2018). Subnational institutions and location choice of emerging market firms. Journal of International Management, 24(4), 317-332. https://doi.org/10.1016/j.intman.2018.04.002

Yang, Y., Martins, P. S., \& Driffield, N. (2013). Multinational performance and the geography of FDI: Evidence from 46 countries. Management International Review, 53(6), 763-794. https://doi.org/ 10.1007/s11575-013-0180-5

Yao, Y., \& Zhou, Y. (2019). Research on Outward Direct Investment in Emerging Economies. In 3rd International Seminar on Education Innovation and Economic Management (SEIEM 2018) (pp. 300-303). Atlantis Press. https://doi.org/10.2991/seiem-18.2019.78

Yiu, D. W., Lau, C., \& Bruton, G. D. (2007). International venturing by emerging economy firms: The effects of firm capabilities, home country networks, and corporate entrepreneurship. Journal of International Business Studies, 38(4), 519-540. https://doi.org/10.1057/palgrave.jibs.8400278

Zeschky, M., Widenmayer, B., \& Gassmann, O. (2011). Frugal Innovation in Emerging Markets. Research-Technology Management, 54(4), 38-45. https://doi.org/10.5437/08956308X5404007

Zhang, Y., Li, H., Li, Y., \& Zhou, L.-A. (2010). FDI spillovers in an emerging market: The role of foreign firms' country origin diversity and domestic firms' absorptive capacity. Strategic Management Journal, 31(9), 969-989. https://doi.org/10.1002/smj.856

Zhang, Y. A., Li, Y., \& Li, H. (2014). FDI spillovers over time in an emerging market: The roles of entry tenure and barriers to imitation. Academy of Management Journal, 57(3), 698-722. https://doi.org/ 10.5465/amj.2011.0351

Zhou, C., Hong, J., Wu, Y., \& Marinova, D. (2019). Outward foreign direct investment and domestic innovation performance: Evidence from China. Technology Analysis \& Strategic Management, 31(1), 81-95. https://doi.org/10.1080/09537325.2018.1485890

Publisher's Note Springer Nature remains neutral with regard to jurisdictional claims in published maps and institutional affiliations. 